\title{
Crosstalk between Notch, HIF-1 $\alpha$ and GPER in Breast Cancer EMT
}

\author{
Ernestina M. De Francesco ${ }^{1,2}$, Marcello Maggiolini ${ }^{1, *}$ (1) and Anna Maria Musti ${ }^{1, *}$ \\ 1 Department of Pharmacy, Health and Nutritional Sciences, University of Calabria, 87036 Rende, Italy; \\ ernestina.defrancesco@manchester.ac.uk \\ 2 Breast Cancer Now Research Unit, Division of Cancer Sciences, Manchester Cancer Research Centre, \\ University of Manchester, Wilmslow Road, Manchester M20 4GJ, UK \\ * Correspondence: marcellomaggiolini@yahoo.it (M.M.); annamaria.musti@unical.it (A.M.M.)
}

Received: 1 June 2018; Accepted: 9 July 2018; Published: 10 July 2018

\begin{abstract}
The Notch signaling pathway acts in both physiological and pathological conditions, including embryonic development and tumorigenesis. In cancer progression, diverse mechanisms are involved in Notch-mediated biological responses, including angiogenesis and epithelialmesenchymal-transition (EMT). During EMT, the activation of cellular programs facilitated by transcriptional repressors results in epithelial cells losing their differentiated features, like cell-cell adhesion and apical-basal polarity, whereas they gain motility. As it concerns cancer epithelial cells, EMT may be consequent to the evolution of genetic/epigenetic instability, or triggered by factors that can act within the tumor microenvironment. Following a description of the Notch signaling pathway and its major regulatory nodes, we focus on studies that have given insights into the functional interaction between Notch signaling and either hypoxia or estrogen in breast cancer cells, with a particular focus on EMT. Furthermore, we describe the role of hypoxia signaling in breast cancer cells and discuss recent evidence regarding a functional interaction between HIF- $1 \alpha$ and GPER in both breast cancer cells and cancer-associated fibroblasts (CAFs). On the basis of these studies, we propose that a functional network between HIF-1 $\alpha$, GPER and Notch may integrate tumor microenvironmental cues to induce robust EMT in cancer cells. Further investigations are required in order to better understand how hypoxia and estrogen signaling may converge on Notch-mediated EMT within the context of the stroma and tumor cells interaction. However, the data discussed here may anticipate the potential benefits of further pharmacological strategies targeting breast cancer progression.
\end{abstract}

Keywords: notch signaling; GPER; estrogen; hypoxia; breast cancer; EMT; cancer associated fibroblast

\section{Introduction}

The Notch signaling is an evolutionary conserved cell-cell communication mechanism operating in many cell types and at various developmental stages to determine cell-fate of neighboring cells. During mammal development, Notch signaling controls various aspects of organogenesis, including neurogenesis, vasculogenesis, myogenesis, and hematopoiesis [1]. Besides, the Notch pathway is also implicated in the regulation of cell proliferation and cell death [2]. In mammals, four different Notch transmembrane receptors can be activated by membrane-tethered ligands. Ligand interaction initiates a proteolytic cleavage of Notch receptors and the subsequent release of the Notch intracellular domain (NICD), which in turn translocates to the nucleus and regulates context-specific patterns of gene expression. This fairly simple core pathway is made complex by a number of secondary proteins, which can be activated by concurrent signaling pathways and modulate various steps of the Notch core pathway, so contributing to signal diversity. As predicted from Notch capacity to operate in 
several tissues, anomalous deregulation of this pathway has been associated with several human diseases, including cancer. Alteration of the Notch signaling pathway is a common feature of different types of malignancies, including hematopoietic and solid tumors. Several studies indicate that in T cell acute lymphoblastic leukemias (T-All), the occurrence of activating mutations in Notch genes is the principal causative factor initiating tumorigenesis, mostly through deregulation of cell-cycle progression and inhibition of apoptosis [3]. Differently, in solid tumors, multiple mechanisms underlie pro-tumorigenic activity of the Notch pathway. These mechanisms include the altered expression of Notch receptors and ligands, ligand-independent activation of Notch, anomalous regulation of Notch degradation and endocytic trafficking, as well as epigenetic control of Notch-dependent transcription $[4,5]$. Accumulating evidence indicates that the Notch pathway is a common avenue for epithelial mesenchymal transition (EMT) triggered by several tumor microenvironmental cues, including hypoxia and estrogens. In this regard, the alternate estrogen receptor GPER has been shown to induce EMT through activation of the Notch pathway [6]. Similarly, in different types of cancer cells hypoxia-activated HIF- $1 \alpha$ has been shown to promote EMT by potentiating the Notch signaling pathway [7]. The aim of this review is to outline the most significant findings supporting the proposal that a signaling network between HIF- $1 \alpha$, GPER and Notch may integrate tumor microenvironmental cues to induce robust EMT in breast cancer cells. In the first part of this review, we describe the Notch core pathway, focusing on possible mechanisms regulating Notch endocytic trafficking and Notch target-gene selection in cancer cells. Following a briefly description of the current knowledge concerning the role of Notch signaling in cancer angiogenesis and EMT, we then discuss the most significant studies providing evidence for a functional crosstalk between estrogen and Notch signaling in breast cancer cells. Likewise, we highlight studies giving insights into the interplay between HIF- $1 \alpha$ and Notch signaling in cancer EMT. In the second part of this review, we describe the role of hypoxia signaling in breast cancer cells and discuss recent evidence regarding a functional interaction between HIF- $1 \alpha$ and GPER in both breast cancer cells and cancer-associated fibroblasts (CAFs). On the basis of these studies we propose that a signaling network between HIF- $1 \alpha$, GPER, and Notch, initiated by either HIF-1 $\alpha$ in hypoxic cancer cell or E2/GPER in normoxic cancer cells, may account for Notch-dependent induction of Snail, a key transcriptional repressor of E-cadherin in breast cancer EMT.

\section{The Notch Core Pathway}

Notch consists of a family of singlepass transmembrane receptors (Notch1-4), which can be activated by the interaction with membrane-tethered ligands, including Delta-like (Dll) 1-4 and Jagged (Jag) 1-2 [8]. The Notch native polypeptide consists of an extracellular domain (NECD) and a transmembrane intracellular domain (NTMIC). The newly synthetized Notch polypeptide is glycosylated throughout the NECD domain in the trans Golgi. The NECD is then cleaved at site 1 (S1) by a furin-like convertase to generate the NECD/NTMIC heterodimer receptor expressed on the cell surface. Upon ligand activation, a conformational change exposes NTMIC for a cleavage by ADAM metalloproteinases at site 2 (S2) generating the membrane-anchored Notch extracellular truncation (NEXT) fragment. In turn, NEXT is cleaved by $\gamma$-secretase at site 3 (S3) and releases the Notch intracellular domain (NICD). Thereafter, NICD translocates to the nucleus and regulates transcription of target genes by forming a complex with DNA-bound RBP-jk, also referred to as CSL, hence triggering the recruitment of co-regulator of transcription Mastermind-like (MAML) family member [9]. In absence of NICD, CSL interacts with various transcriptional repressors, which are then substituted by MAML in response to Notch activation (Figure 1).

This initial model of Notch-mediated transcriptional activation has been further characterized by several studies showing that CSL-binding co-repressors are mostly complexes of histone modifying enzymes keeping the chromatin in a compact inactive state; whereas MAML proteins recruit transcriptional co-activators, mostly p300/CBP, with histone-acetylation enzymatic activity [10]. Moreover, accumulating evidence suggests that the recruitment of NICD-CSL at promoter/enhancer induces dynamic histone epigenetic modifications [11], in turn favoring accessibility of either the 
tripartite complex NICD-CSL-MAML or repressor-bound CSL [12]. Such a mechanism could set a threshold concentration of the tripartite NICD-CSL-MAML complex for the displacement of the repressor-CSL complex from the target promoter; on the other side, it could guarantee a rapid switch off of Notch-dependent transcription upon decay of the inducing signal. Further studies are required to assess whether such a mechanism is context-specific or applies to most Notch-responsive genes.

\section{Notch Endosomal Trafficking and Ligand-Independent Activation}

A variety of post-translational events, including ubiquitination and endocytic trafficking have been shown to regulate the Notch core pathway, allowing context specific regulation. Upon liganddependent generation of the membrane-bound NEXT fragment, Notch activation proceeds through the $\gamma$-secretase-dependent proteolytic cleavage at S3 to release NICD, which mostly occurs at the cell surface. However, studies in Drosophila development have revealed that S3 cleavage of NEXT also occurs after internalization in early endosomes [13] and endosomal entry is required for efficient activation of the pathway [13] (Figure 1). In line, positive regulators of endosomal trafficking, such as Dynimin and Rab5, have been shown to promote canonical ligand-dependent activation of Notch signaling [14]. Furthermore, earlier studies in human cells have shown that Notch monoubiquitination is required for both the internalization in early endosome and $\gamma$-secretase cleavage [15]. Several studies suggest that the E3 ubiquitin ligase Deltex is the enzyme responsible for NEXT monoubiquitination and internalization in early endosomes [16]. Adding a further level to the regulation of Notch endocytic trafficking, Moretti et al. [17] showed that NEXT deubiquitination is also required for $\gamma$-secretase cleavage and release of NICD. Major negative regulators of Notch endocytic activation are Numb and Numb-like proteins, which alter the endocytic route of Notch receptor by promoting its degradation [18]. Besides their function in cell fate decision during development [18], Numb proteins act as tumor-suppressor of oncogenic Notch signaling during tumorigenesis [19].

In absence of ligand binding the Notch heterodimer undergoes endocytic turnover, a process requiring Notch polyubiquitination by the Su (dx)/Itch/AIP4 E3 ubiquitin ligase [20,21], in turn allowing Notch internalization in early/late endosomes. In late endosomes, multiubiquinated Notch is then sorted to the multi vesicular body (MVB), through a serial-steps mechanism operated by the endosomal sorting complex required for transport (ESCRT) system; finally, upon MVB fusion with lysosomes, the Notch receptor is eventually degraded [22] (Figure 1). Studies in Drosophila mutants have shown that deficiencies of various components of the ESCRT system lead to ligand-independent activation of Notch, through a mechanism allowing $\gamma$-secretase cleavage in late endosomes and the consequent release of NICD (Figure 1) [22-24].

Moreover, studies in Drosophila crystal cells indicate that endocytic activation of unligated Notch is regulated by Sima, the ortholog of mammal HIF-1 $\alpha$ [25]. This study shows that Sima promotes crystal cell survival by allowing accumulation of full-length Notch in early endosome and its subsequent ligand-independent activation. Furthermore, this study reports that overexpression of Rab5 suppresses the effect of Sima on crystal cell survival, presumably by increasing Notch endocytic turnover. Notably, HIF-1 $\alpha$ was previously demonstrated to downregulate the Rab5 effector rapabtin-5, thereby the endocytic pathway [26]. These results suggest that the regulation of Notch endocytic sorting may represent a further point of crosstalk between Notch and signaling pathways activated by tumor microenvironmental cues. It would be interesting to assess whether in human cancer cells, hypoxia-activated HIF- $1 \alpha$ may lead to ligand-independent activation of Notch signaling by mimicking the effect of Sima on Notch endocytic trafficking. Thus far, there is no direct evidence for oncogenic mutations targeting the Notch endocytic pathway in human cancer. However, Notch endocytic sorting and proteolytic maturation has been shown to occur also in mouse and human cells [27]. In line, vacuolar $\mathrm{H}^{+}$ATPase (V-ATPase), whose activity is required for acidification of endocytic organelles, was shown to be required for endosomal cleavage of NEXT by $\gamma$-secretase, both in Drosophila and human cells [28]. In particular, this study has shown that in normal human breast cells, pharmacological inhibition of either V-ATPase (by BafA1) or $\gamma$-secretase (by DAPT) 
reduced with similar efficiency the steady-state levels of NICD, as well as the expression levels of the Notch target gene Hes1. These results indicate that endocytic maturation of Notch is the major route for Notch activation in normal breast cells. Yet, the authors showed that in the breast cancer cell line HHCC1599, harboring a gene rearrangement of Notch1 causing ligand-independent, but $\gamma$-secretase dependent activation of Notch [29], BafA1 had a smaller effect than DAPT in reducing the steady-state levels of NICD and Hes1. This observation suggests that constitutive expression of oncogenic Notch, structurally similar to the NEXT fragment, favors $\gamma$-secretase cleavage at the plasma membrane. Interestingly, previous studies by Tagami and collaborators [27] indicated that depending on the subcellular location of NEXT proteolytic cleavage, the precise location of the S3 cleavage-site by $\gamma$-secretase can shift to the next few residues, producing NICDs that vary in their PEST domain and consequently in their stability. Moreover, these various form of NICDs generated different intensity of Notch signaling [27]. In particular, this study showed that the NICD generated at the plasma membrane was the major form present in Hela cells and was more stable than the NICD generated in early endosome. These observations indicate that the specific subcellular location of NEXT proteolysis may determine the duration of Notch signaling in signal-receiving target cell. Taken together, these studies suggest that certain oncogenic variations of Notch protein structure may strengthen Notch signaling by altering the subcellular location of $\gamma$-secretase proteolysis, in turn enhancing Notch signaling in cancer cells.

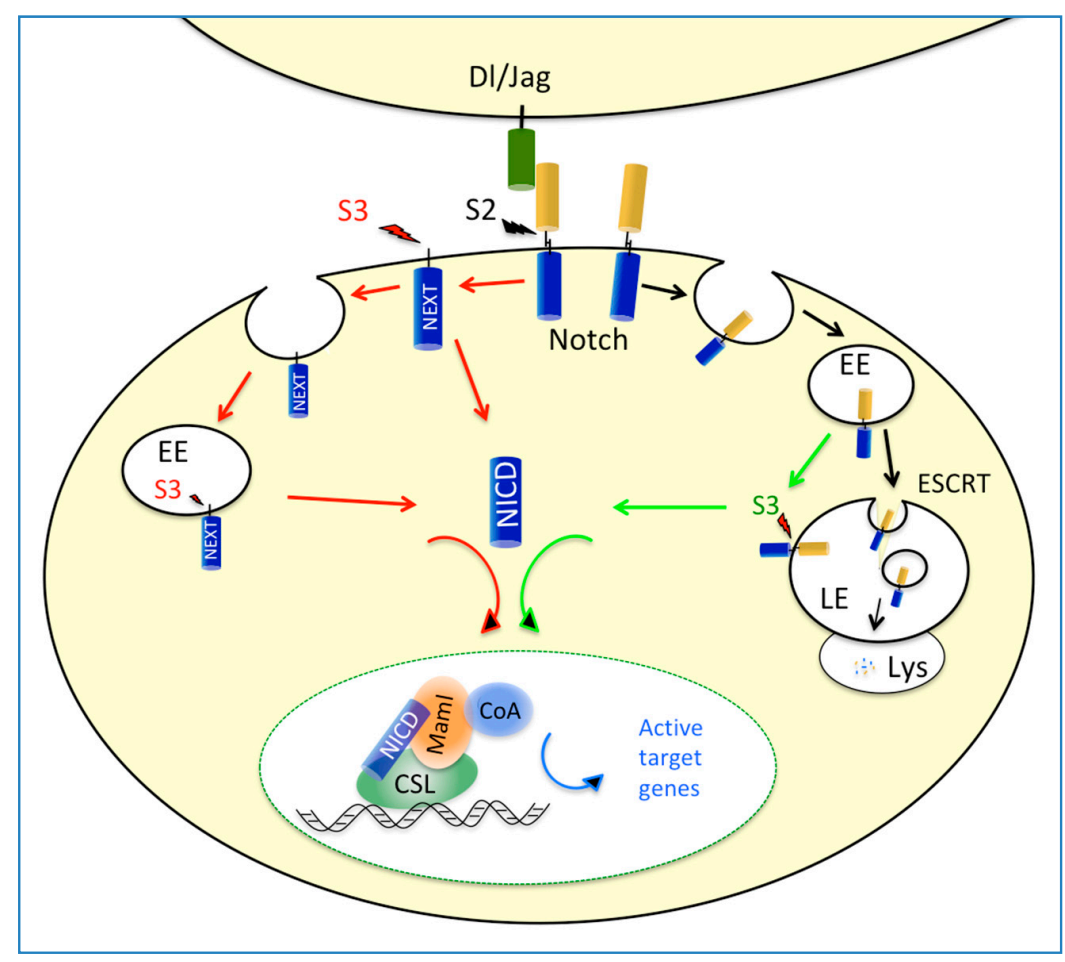

Figure 1. The Notch core pathway and endocytic routes to ligand-dependent and ligand-independent activation of Notch signaling. Red arrows indicate canonical paths of Notch activation initiated by Notch/Ligand (Dl/Jag) binding and generating Notch intracellular domain (NICD) molecules upon sequential proteolytic cleavage of Notch at site 2 (S2) and 3 (S3), by Adam metalloproteases and $\gamma$-secretase, respectively. Black arrows indicate the endocytic route of unbound Notch receptor regulated by the endosomal sorting complex required for transport (ESCRT) system and culminating with Notch degradation in late endosome (LE) fused to lysosome (Lys). Green arrows indicate the alternative endocytic path of unbound Notch, allowing Notch to escape degradation and whereas generation of NICD. Both red and green paths culminate with nuclear translocation of NICD and its recruitment at CSL-bound promoters, which triggers the exchange of CSL-bound co-repressor with Maml and co-activators of transcription. 


\section{NICD Transcriptional Strength and Target Selection}

Depending on spatial and temporal context, the functional output of Notch signaling may be radically different, ranging from cell stemness to differentiation and cell death. As described above, Notch-dependent transcription is based mostly on the CSL-NICD-MAML transcriptional complex, yet capable of inducing context-specific gene expression patterns. A recent review discussed the wide number of studies providing important insights into the possible factors governing context-specific expression of Notch target genes [8]. Here, we will briefly consider those factors that may influence target-gene selection by modulating NICD stability, or by regulating the cooperation of NICD with specific transcription factors.

Since Notch acts as a ligand-activated transcription factor, the expression levels of both membrane-bound Notch and the processed intracellular NICD are crucial for the signaling strength and duration of the signaling, as proved by Notch1 haploinsufficiency in several diseases [30]. NICD stability is mostly controlled by the E3 ubiquitin ligase Fbw7, which targets the NICD C-terminal domain for ubiquitination and consequent degradation [31]. Several studies have shown that Notch oncogenic mutations map in the Fbw7 degron domain of Notch, avowing NICD degradation and leading to reinforcement of Notch signaling [10]. Similarly, in vivo abrogation of Fbw7 expression in mesenchymal stromal cells (MSCs) induces NICD stabilization and the consequent up-regulation of the $\mathrm{CCl} 2$ chemokine, which in turns promoted breast cancer metastasis in mice [32]. $\mathrm{CCl} 2$ expression in MSCs was shown to be strictly dependent on NICD recruitment at the promoter of CCL2 gene, suggesting that environmental variation of Fbw7 expression might determine the selection of novel Notch-target genes in the tumor microenvironment. Interestingly, Fbw7 expression is negatively regulated by extrinsic cues activating oncogenic signaling [33,34].

Certainly, the context-specific expression pattern of canonical ligands and receptors also participate to the diversity of Notch functional output and represent an important crosstalk road with other signaling pathways [8]. However, studies from Liu at al. [35] suggest that the different biological outputs of Notch-1 and Notch-2 may reflect different strengths of the respective signals. In particular, this study shows that the structural differences present in the NEXT fragments generated by Nocht- 1 or Notch-2 receptors affect the subcellular location of their respective S3 cleavage by $\gamma$-secretase, with the Notch2-NEXT being more frequently cleaved at the cell surface than the Notch1-NEXT. Interestingly, the NICD/Notch2 resulted in having greater signal strength than the NICD/Notch1, confirming previous studies by Tagami et al. (discussed above) showing that the subcellular location of NEXT proteolytic cleavage can determine the strength of Notch signaling [27]. Together these studies suggest that context-dependent location of S3 cleavage of NEXT fragments may contribute to gene-target selection by discriminating between genes responding to different transcriptional strength of the Notch signaling.

Genome wide studies have indicated that NICD/CSL complex occupies only a limited number of the CSL canonical motif present in the genome [36]. This observation suggests that other transcription factors (TF) may promote the recruitment of NICD/CSL complex at specific promoters or enhancers, so contributing to gene-target selection. For instance, studies in T-lymphoblastic leukemia cells have shown that CSL binding motifs are often located in enhancers containing histone modifications typical of active chromatin, which favor DNA accessibility [37]. This study also shows that within several of these active enhancers, the CSL binding site overlaps with that of Runx, a TF required for T-cell development [37]. Notably, the study demonstrated the requirement of Runx for the expression of Notch-target genes, suggesting that cooperation of NICD/CSL with lineage specific TFs may be crucial for Notch-target selection. Cooperation with signal-induced TFs may also augment CSL-NICD activity at specific target genes. For example, a study by Sahlgren et al. (discussed later in this review) has shown that in human ovarian carcinoma cells hypoxia-activated HIF- $1 \alpha$ is recruited together with NICD at the promoter of the Notch-target Snail-1 gene, hence increasing Snail-1 expression [38]. Similarly, $\beta$-catenin is recruited at the promoter of Notch-target genes during the differentiation of arterial endothelial cells from vascular progenitor cells [39]. 


\section{Notch Signaling in Tumor Angiogenesis and EMT}

\subsection{Angiogenesis}

Angiogenesis consists in the generation of new blood vessels from preexisting vasculature. In normal tissues, angiogenesis is initiated by hypoxia-stimulated production of the vascular endothelial growth factor (VEGF), which stimulates the formation of a new sprout, whose very front cell is called a "tip" cell. In response to VEGF, the tip cell extends several filopodia towards the VEGF gradient, whereas the adjacent endothelial cells, named stalk cells, do not respond to VEGF, but proliferate and form the lumen of the branching vessel [40]. This selection of the tip and the stalk cell fate is critical for successful angiogenesis and is based on the type of Notch ligands expressed on the tip and stalk cells. In particular, the tip cell is stochastically-determined by VEGF stimulation, which in turn induces the expression of the Notch ligand Dll4. In turn, Dll4 induces Notch signaling in the adjacent endothelial cell expressing Notch receptors. Through an inhibitory mechanism, named lateral inhibition [8], Notch signaling inhibits the expression of Dll-type of receptors and VEGFR2, hence determining the peculiar stalk cell phenotype [40]. The VEGF/Dll4/Notch pathway also functions in cancer angiogenesis, where changes in the expression levels of signaling molecules, including Notch ligands Dll4 and Jag1, lead to altered morphological features of the vascular endothelium [41-43]. Furthermore, in tumor models, blockade of Dll4-Notch signaling results in vessel hypersprouting, nonfunctional tumor vasculature, and inhibition of tumor growth [44,45]. Besides, deregulated expression of Notch ligands in endothelial cancer cells may also regulate invasiveness by promoting Notch activation of adjacent cancer cells [46]. Similarly, Jag1 secreted from tumor endothelial cells promotes the cancer stem cell phenotype of colorectal carcinoma cells [47].

\subsection{EMT}

Epithelial-mesenchymal transition (EMT) is a conserved process occurring during both embryonic development cancer and progression, through which polarized epithelial cells become migratory mesenchymal stem cells [48]. During embryogenesis of both invertebrate and vertebrates, multiple rounds of EMT are crucial for the formation of tissues and organs [48,49]. In cancer progression, EMT confers migratory and invasive features to epithelial cancer cells and is mainly achieved through transcriptional repression of junctional proteins, among which the cell-cell adhesion molecule E-cadherin is repressed in several invasive carcinomas [48]. Various highly conserved signaling pathways operating in embryonic development are known to trigger EMT in cancer cells. Among these pathways, Wnt, TGF-beta and Notch signaling converge at the induction of direct transcriptional repressors of E-cadherin, including Snail/Slug, Twist and ZEB1/2 [48,50]. Accumulating evidence suggest that Notch-dependent up-regulation of Snail/Slug expression mediates the induction EMT by interacting signaling pathways, as TGF-beta, hypoxia, and estrogen/GPER [6,38,51,52]. Being downstream of multiple signaling pathways leading to EMT, Snail expression positively correlates with metastasis and poor prognosis in different types of tumors [50]. Snail has been shown to repress E-cadherin expression by recruiting histone-modifying enzymes at the CDH1 gene promoter (coding E-cadherin protein), including Sin3A-HDAC1/2 [53], Polycomb complex 2 (PRC2) [54] or Lysisn-specific demethylase 1 (LSD1) [55], which turn chromatin into an inactive state. In different types of cancer cells, Notch signaling promotes EMT by directly inducing Snail expression $[6,38,56,57]$. At transcriptional level, Notch regulates Snail expression through the tripartite complex NICD-CSL-MAML-1, as demonstrated by the evidence that the dominant-negative mutant of MAML-1 (DN-MAML-1) inhibits Snail expression and EMT in cancer cells [6,38]. As discussed later in this review, Notch also controls Snail protein expression by an indirect mechanism augmenting Snail protein stability in hypoxic cancer cells [38]. 


\section{Interplay between Notch Signaling and $17 \beta$-Estradiol (E2) in Breast Cancer}

Earlier studies in breast cancer reported that high expression levels of Notch1 and Jag1 were associated with poor prognosis [58], suggesting a possible interplay between estrogen and the Notch signaling pathway. Furthermore, Stylianou et al. [59] observed accumulation of NICD in a wide variety of human breast cancer cell lines and tissue samples, indicating that the Notch pathway may be aberrantly activated in human breast cancer. Estrogens mainly act through the cognate receptors namely $E R \alpha$ and $E R \beta$, which upon hormone binding translocate to the nucleus and function as transcription factors regulating estrogen-responsive genes [60]. Studies by Rizzo et al. [61] documented a negative crosstalk between ER $\alpha$ and the Notch signaling in breast cancer cells. Results from this study suggest that E2-activated ER $\alpha$ causes an accumulation of inactive membrane-bound Notch1, which was in part due to inefficient $\gamma$-secretase cleavage of the Notch receptor. However, E2 did not cause inhibition of $\gamma$-secretase activity, suggesting that E2-activated ER $\alpha$ may effect Notch endocytic trafficking. A negative interplay between Notch1 and ER $\alpha$ was confirmed by Haughian et al. [62], as in $\mathrm{ER}^{+}$luminal breast cancer Notch-1 signaling mediated the expansion of a luminobasal $\mathrm{ER}^{-}$ subpopulation of cells, which arose upon endocrine therapy. Interestingly, Stinson et al. [63] identified miR-221/222 as the two miRNAs whose expression pattern can clearly discriminate between the $\mathrm{ER}^{-}$luminobasal and the $\mathrm{ER}^{+}$luminal subtypes of breast cancer. Moreover, the transfection of miR-221/222 transfection in a human mammary epithelial cell line promoted EMT by targeting TRPS1, a member of the GATA family transcriptional repressor [64], which repressed the expression of the EMT transcription factor ZEB2. Interestingly, a recent study by Golan et al. [65] showed that Notch-1 activation in melanoma cells directly derepresses miR-221/222 expression, therefore promoting melanoma invasion. Notably, the ESR1 gene (encoding ER $\alpha$ ) resulted in a major target of miR-221/222 and its knockdown mirrored the effect of miR-222 overexpression on melanoma invasive activity. Furthermore, Han et al. reported that in ER ${ }^{+}$breast cancer, miR-222 is associated with down-regulation of ER $\alpha, E M T$, and tumor progression [66]. On the other hand, earlier studies in breast cancer showed that ER $\alpha$ promoted metastasis-associated family member 3 (MTA3)-dependent repression of Snail and E-cadherin expression [67]. A few years later, the same group proposed an inverse mechanism, showing that in non-invasive MCF7 cancer cells, Snail induces EMT features by directly repressing ER $\alpha$ expression [68]. A recent study reported a similar mechanism of ER $\alpha$ repression by Slug in human breast cancer [69]. Taken together, these studies suggest a mutual functional repression between Notch1 and ER $\alpha$ signaling in breast cancer EMT, where ER $\alpha$-responsive genes (e.g., MTA3) would repress the expression of EMT-transcription factors laying downstream the Notch pathway. Conversely, Notch target genes (e.g., miR-221/222 or Snail) would repress ER $\alpha$ expression. Presumably, in normal breast epithelial cells these two opposing signaling pathways act in an opposite manner, whereas during malignant transformation, either intrinsic variations or microenvironmental signals may disrupt this balance and favor the expression of aggressive phenotypes in breast cancer.

Beyond ER $\alpha$ and ER $\beta$, estrogens signal through the G-protein coupled estrogen receptor, a member belonging to the rhodopsine-like family of G-protein coupled receptors (GPCRs) [70]. GPER has been shown to unlock access to estrogens in breast cancer cells devoid of the classic Estrogen Receptor (ER), thus allowing the stimulatory actions of these steroids [70]. In estrogen-responsive tumors, GPER expression correlates with negative clinical-pathological features such as larger tumor size, distant metastasis, and worse prognosis [71-74]. In accordance with these observations, GPER signaling has been linked to ER $\alpha$ loss, which occurs in breast cancer cells undergoing tamoxifen resistance [75]. GPER mediates rapid estrogen action via heterotrimeric $G$ proteins, hence activating multiple intracellular pathways regulating crucial mechanisms involved in breast cancer growth, invasion, and metastasis [76]. As discussed in the next sections, GPER also signals in cancer-associated fibroblasts (CAFs), therefore contributing to the expression of pro-tumorigenic factors within the tumor microenvironment, as inflammatory cytokines and angiogenic factors [77]. Regarding breast cancer invasiveness, previous studies showed that in ER-negative breast cancer cells or CAFs, E2/GPER 
signaling induced cell migration through EGFR-dependent activation of connective tissue growth factor (CTGF) $[78,79]$. The following studies showed that GPER interacts with multiple signaling pathways culminating with the expression of various molecules inducing cell migration in breast cancer cells [80-82]. As it concerns Notch signaling, our previous studies showed that estrogen engages a positive crosstalk between GPER and the Notch pathway, triggering Notch/Snail-mediated EMT in both ER $\alpha$ positive and ER $\alpha$ negative breast cancer cells, as well as in CAFs [6]. In particular, we demonstrated that E2/GPER signaling induced ligand-independent activation of Notch1 and Notch target genes, including the EMT-transcription factor Snail, whose activation required the tripartite NICD-CSL-MALM-1 transcriptional complex. Most importantly, breast cancer cells acquired invasion properties and lost Cadherin expression in a GPER/Notch dependent fashion. Of note, our study showed that E2/GPER signaling induced both Notch1 mRNA and NICD protein levels [6]. Further studies are required to elucidate whether and how the increase of NICD levels observed by GPER signaling is directly linked with ligand-independent activation of Notch.

\section{Crosstalk between HIF-1 $\alpha$ and Notch in Cancer EMT}

As discussed in the next Section, the homeostatic function of hypoxia during normal development and in pathophysiology is mostly mediated by the activation of HIF- $1 \alpha$ transcription factor and the subsequent induction of its target genes, primarily acting in angiogenesis [83] and energy metabolism [84]. Hypoxia-activated HIF-1 $\alpha$ is also involved in cellular processes controlling phenotypes of stem cells during embryogenesis [85], as well as in cancer stem cells (CSCs) during tumor initiation and progression [86]. Likewise, the Notch signaling pathway has been shown to be crucial for stem cell maintenance and cell fate control, both during development and cancer progression [87]. Such a functional similarity between these two signaling pathways has prompt researchers to assess possible functional interactions, both in developmental and cancer biology. Indeed, as remarkably discussed in a recent review [7], several studies have shown that certain functional outputs of the hypoxic response, as the regulation of stem cell differentiation [88], require the expression of Notch target genes. As regards cancer, first hints for a HIF- $1 \alpha /$ Notch crosstalk came from a transcriptomic analysis showing the upregulation of Notch target genes in hypoxic neuroblastoma cells [89]. Recently, a gene expression analysis of Notch and hypoxia-activated genes in glioblastoma tumors confirmed a combined gene signature of these two pathways and its relevance in tumor prognosis [90]. Same trends have been reported in different types of brain tumors [7].

EMT confers migratory and invasive features to epithelial cancer cells and is mainly achieved through transcriptional repression of E-cadherin. As discussed earlier, Notch signaling represses E-cadherin expression mostly through the induction of Snail/Slug transcriptional effectors [48]. Hypoxia is often an environmental feature of the tumor invasive front, where the EMT program takes place. Hypoxia-activated HIF- $1 \alpha$ induces cancer EMT through diverse molecules and pathways, including inflammatory cytokines, epigenetic regulators, and transcription factors/repressors [91]. As it concerns the induction of Snail by hypoxia, first indications came from studies in ovarian cells lines, where HIF- $1 \alpha$ was shown to induce EMT through up-regulation of Snail expression and consequent repression of E-cadherin [92]. Snail expression is regulated at multiple levels, including transcriptional expression and protein stabilization [50]. Of note, hypoxia has been shown to influence both levels of Snail regulation. For instance, hypoxia-induced HIF- $1 \alpha$ was shown to indirectly inhibit Snail ubiquitination by inducing Sox-9-dependent expression of the USP47 deubiquitinase in lung cancer cells [93]. On the other hand, hypoxia was shown to induce Snail regulation through a synergistic mechanism between Notch-NICD and HIF-1 $\alpha$ [38]. Firstly, hypoxia indirectly induced Snail-1 transcription by promoting a HIF- $1 \alpha /$ NICD physical interaction, which in turn increased the recruitment of NICD to the Snail-1 promoter; next, Notch increased the recruitment of HIF-1 $\alpha$ to the lysyl oxidase (LOX) promoter region, hence triggering LOX expression. As a consequence, LOX stabilized Snail protein levels, which migration and invasion of breast cancer cells [38]. A further study confirmed the role of Notch signaling in mediating the effect of hypoxia toward the activation of Snail 
and Slug in breast cancer cells [94]. In particular, this study showed that HIF-1 $\alpha$ binds to the promoter of Notch target genes Hes1 and His2 and cooperates with the transcriptional coactivator MALM1 to potentiate transcriptional events. Similarly, HIF- $1 \alpha$ was shown to induce EMT in oral squamous cell carcinoma by inducing Notch-dependent activation of Snail [95]. As mentioned above, Snail represses E-cadherin expression by recruiting different histone-modifying enzymes at the CHD1 promoter [96]. Regarding this topic, HIF- $1 \alpha$ was shown to induce the expression of HADC3, which cooperated with Snail to repress E-cadherin expression along with other epithelial-specific genes [97]. It remains to be elucidated whether such a mechanism also contributes to the repression of E-cadherin mediated by Notch signaling in hypoxic cancer cells.

On the other hand, Villa and collaborators discovered that hypoxia-activated HIF- $1 \alpha$ induces Notch signaling independently from its transcriptional activity [98]. The mechanism consists of a direct interaction between HIF- $1 \alpha$ and $\gamma$-secretase that enhances $\gamma$-secretase activity and Notch cleavage at site S3. In line with this model, the aforementioned study showed that inhibition of either $\gamma$-secretase activity or a transcriptional coactivator of Notch-NICD prevents the invasiveness of breast cancer cells [98]. The non-transcriptional role of HIF- $1 \alpha$ in the activation of Notch signaling was further confirmed in lung adenocarcinoma cancer cells, where cadmium exposure was shown to induce EMT by Notch-dependent expression of Snail, in a HIF-1 $\alpha$ dependent manner [57].

\section{Hypoxia-Inducible HIF-1 $\alpha$ in Breast Cancer Cells and CAFs}

\subsection{HIF-1 $\alpha$ in Breast Cancer Cells}

Solid malignancies like breast cancer possess a unique microenvironment often characterized by hypoxia $[99,100]$. Low oxygen $\left(\mathrm{O}_{2}\right)$ occurs in certain neoplastic areas when the balance between $\mathrm{O}_{2}$ consumption and $\mathrm{O}_{2}$ supply is lost. Indeed, the highly metabolic demands of cancer cells, the disorganized and leaky tumor vasculature, as well as the mechanic pressure exerted by the growing tumor mass on existing capillaries and blood vessels, all together limit $\mathrm{O}_{2}$ diffusion and reduce its availability [99]. Hypoxia, which has been included among the hallmarks of cancer, is associated with genetic instability and chemo/radio-resistance, as well as disease progression and evolution toward metastatic phenotypes $[100,101]$. Thereafter the broad range of molecular and cellular responses triggered by low $\mathrm{O}_{2}$ tension in the tumor microenvironment is currently under the magnifying lens for the enormous clinical potential [102,103]. In breast cancer, regions of hypoxia have been detected in all stages, however only tumors with worse prognostic features, as lack of estrogen receptor (ER) and progesterone receptor (PR) or node-positive status, are characterized by higher degree of hypoxia and major extent of low $\mathrm{O}_{2}$ areas [104]. The pivotal molecular mechanisms and biological responses influencing breast cancer outcome in hypoxic microenvironment are triggered by the hypoxia inducible factors (HIFs) [105-107]. HIF-1, HIF-2, and HIF-3 are oxygen-regulated, basic helix-loop-helix (bHLH)-containing PER-ARNT-SIM (PAS) transcription factors which sense and respond to fluctuation of $\mathrm{O}_{2}$ levels [108-110]. While HIF-1 is expressed ubiquitously in human cells, the expression of HIF-2 and HIF-3 is restricted to certain tissues [111]. Furthermore, it has been established that HIF-1 acts as an immediate but transient effector in severe hypoxia, while HIF-2 responds to moderate drop in $\mathrm{O}_{2}$ levels [112]. HIF- $1 \alpha$ has long been recognized as a pivotal orchestrator of the cancer cell responses to hypoxic microenvironment, by regulating the expression of genes involved in metabolic reprogramming and $\mathrm{pH}$ balance, cell proliferation/survival, apoptosis, angiogenesis, stem cell maintenance, matrix remodeling, metastasis, and resistance to radio- and chemo-therapy [107]. Like all the other members of the HIF family, HIF-1 is composed of both an $\mathrm{O}_{2}$-dependent alpha subunit and an obligate binding-partner, the aryl hydrocarbon nuclear translocator (ARNT), also known as HIF1- $\beta[109,110]$. HIF-1 $\alpha$ expression depends on $\mathrm{O}_{2}$ levels, being almost undetectable in normoxic conditions, whereas HIF-1 $\beta$ is constitutively expressed. Under aerobic conditions, HIF- $1 \alpha$ levels are maintained very low due to a tightly regulated mechanism that requires the participation of Prolyl Hydroxylase Domain (PHD) enzymes and the von Hippen Lindau (VHL) tumor-suppressor protein, 
as well as the engagement of the proteasome [113]. In the presence of $\mathrm{O}_{2}, \mathrm{PHD}$ enzymes hydroxylate HIF- $1 \alpha$ subunit at specific proline residues, including Pro402 and Pro564; this reaction requires not only $\mathrm{O}_{2}$, but also iron $\left(\mathrm{Fe}^{2+}\right)$ and alpha-ketoglutarate $(\alpha \mathrm{KG})$ as co-factors. Hydroxylation of HIF-1 $\alpha$ at proline residues serves as a label for HIF- $1 \alpha$ binding to the VHL-E3 ubiquitin ligase complex (composed of elongin B, elongin C, cullin 2, andring-box 1). As a consequence, HIF- $1 \alpha$ is ubiquitinated and then degraded by the proteasome. Beyond PHD enzymes, HIF- $1 \alpha$ activity is negatively regulated by the asparaginyl hydroxylase named FIH-1 (factor-inhibiting HIF-1), which hydroxylates HIF-1 $\alpha$ at a conserved asparagine residue (Asn-803), thus preventing the binding to the transcriptional coactivator $\mathrm{CBP} / \mathrm{p} 300$ which is required for transcriptional activity $[114,115]$.

Under hypoxic conditions, the prolyl and asparaginyl hydroxylation of HIF- $1 \alpha$ is inhibited, resulting in accumulation of HIF- $1 \alpha /$ HIF- $1 \beta$ dimers, hence recruitment of transcriptional co-activators to the promoter of specific target genes carrying the hypoxia-response elements motif, identified as the core sequence $5^{\prime}$-(A/G) CGTG-3' [116,117]. As pivotal players of HIF- $1 \alpha$ regulation, PHDs and VHL are frequently deregulated in breast cancer and may serve as useful prognostic markers. In this regard, positive staining for hydroxylated HIF- $1 \alpha$ at both VHL binding sites (Pro402 and Pro564) identifies a subset of breast cancer patients with poorer prognosis [118]. Similarly, analysis from primary breast cancer samples and human breast cancer cell lines revealed that low levels of VHL correlate with invasive and migratory capacity, as well as with aggressive features of breast disease [119]. Moreover, results from a randomized trial enrolling 211 breast cancer patients undergoing neoadjuvant epirubicin therapy showed upregulated expression of PHD1, PHD2 and PHD3, together with HIF-1 $\alpha$, VEGF and carbonic anhydrase IX (CAIX) [120]. Taken together these studies support the involvement of PHDs and HIF pathways in response to chemotherapy and possibly involved in chemo-resistance. Interestingly, a new physiologically relevant methylation-based mechanism was shown to regulate HIF- $1 \alpha$ stability. In particular, methylation of HIF- $1 \alpha$ on the 32 nd lysine residue by the nuclear SET7/9 methyltransferase triggers HIF-1 $\alpha$ degradation in normoxia, whereas the demethylase LSD1 removes the methyl group, thus increasing HIF-1 $\alpha$ protein stability upon hypoxic conditions [121]. Importantly, analysis on knock-in mice expressing a methylation-resistant HIF- $1 \alpha$ mutant protein confirmed that lysine demethylation is a crucial mechanism regulating hypoxia-induced stability of HIF-1 $\alpha$ in breast cancer [121].

\subsection{HIF-1 $\alpha$ in $C A F s$}

HIF-1 $\alpha$ expression is tightly regulated also within the breast tumor microenvironment, which is recognized as a critical player for disease development and progression [122]. Indeed, endothelial cells, macrophages, adipocytes, and activated fibroblasts in breast cancer contribute to relevant biological responses, including cell proliferation, invasion, metastasis, angiogenesis, immunosuppression, and therapeutic resistance, ultimately leading to the acquisition of malignant features of breast disease [123-125]. Cancer-associated fibroblasts (CAFs) represent the most abundant cell type in breast cancer stroma and mostly derive from normal stromal fibroblasts (NFs) [126,127]. Only a small subpopulation of fibroblasts is quiescent within the breast tumor mass, whereas the majority of fibroblasts show an activated phenotype characterized by the ability to produce various ECM components and paracrine mediators, including growth factors and cytokines [128]. Among the several mechanisms involved in the transition of NFs towards CAFs, local hypoxia was shown to drive the differentiation of NFs into activated myofibroblasts by triggering the formation of Reactive Oxygen Species (ROS), which generate an elevated amount of hydrogen peroxide themselves, thereby boosting the biological responses to hypoxic stress [129-131]. In accordance with these observations, ROS-triggered and HIF-1-dependent metabolic and transcriptional reprogramming in CAFs was shown to promote EMT and metastasis [132]. Furthermore, it was shown that loss of PHD2 (EGLN1) impairs tumor growth and suppresses the pro-metastatic activity of CAFs $[133,134]$. In addition, hypoxia-dependent depletion of PHD2 deactivates CAFs through the loss of $\alpha$ SMA, periostin, and myosin II. In line with these findings, the PHD inhibitor DMOG was shown to 
significantly decrease spontaneous lung and liver metastasis in an orthotopic breast cancer model [135]. Likewise, in a spontaneously arising PyMT-oncogene driven breast cancer model (MMTV-PyMT model), loss of PHD2 is associated with vessel normalization, a reduced CAF activation and a decreased metastatic intravasation [134]. Altogether, these findings suggest that the blockade of PHD2 in CAFs may represent a novel strategy to suppress pro-metastatic signals within the breast tumor microenvironment.

Extending these findings, CAFs action through HIF has been shown to include the regulation of metabolic inter-dependencies between cancer cells and the surrounding microenvironment. Indeed, HIF- $1 \alpha$ is involved in the regulation of a two-compartment metabolic symbiosis between anabolic cancer cells and catabolic stromal fibroblasts [136]. In particular, the increased glycolytic rates exhibited by CAFs are at least in part dependent on HIF signaling [136]. In addition, the high-energy metabolic by-products produced by catabolic CAFs are taken up by tumor cells to support their high anabolic requirements [137]. Interestingly, the elevated metabolic flux of cancer cells generates ROS, which are then propagated within the tumor microenvironment and in CAFs to promote HIF-dependent metabolic reprogramming $[138,139]$.

\subsection{Cytokines Regulating HIF-1 $\alpha$ and NOTCH Signaling in the Tumor Microenvironment}

In the tumor microenvironment, the balance between pro- and anti-inflammatory cytokines deeply influences breast cancer biology, providing a causal connection between inflammation and disease progression. Autocrine and paracrine actions elicited by cytokines and chemokines in the tumor microenvironment control the intricate communications occurring between cancer cells and stromal components toward the acquisition of malignant features [140]. Not surprisingly, several cytokines activate the HIF-1 $\alpha$ pathway, actually evoking a hypoxic-like response in the tumor mass. In addition, many of the tumor-promoting effects induced by cancer-derived cytokines involve Notch-mediated action as the main trigger. Supporting these observations, pro-inflammatory cytokines are known to induce HIF- $1 \alpha$ expression in normoxia [141,142], nevertheless cytokine-dependent effects are also observed in the hypoxic inflammatory tumor microenvironment [143]. In this context, tumor stromal components play a relevant role in mediating paracrine actions occurring at the interface between cancer cells and the hypoxic and inflammatory microenvironment. For instance, the cytokine Oncostatin M, belonging to the Interleukin-6 (IL-6) family of cytokines, enhances HIF- $1 \alpha$ protein stability and induces HIF- $1 \alpha$ de novo synthesis via activation of mTORC2 in breast Tumor Associated macrophages (TAMs), leading to inflammatory reprograming [144]. Worthy, CAFs isolated from breast tumor carcinomas promote angiogenesis by recruiting endothelial progenitor cells through stromal cell-derived factor 1 (SDF-1)/CXCR4 pathway [145], which is known to be activated by HIF-1 $\alpha$ in several stressful conditions [146]. Likewise, cytokines as TGF- $\beta$ and IL-1 $\beta$ may be released by breast cancer cells in a HIF- $1 \alpha$ dependent manner and promote the conversion of normal fibroblasts to CAFs, hence encouraging tumor growth, metastatic spread, and neoangiogenesis [147]. Interestingly, in breast cancer cells both HIF- $1 \alpha$ and TGF- $\beta$ regulate a common set of genes including VEGF and CXCR4, toward the activation of the metastatic program, whereas the combined use of small molecule inhibitors of HIF- $1 \alpha$ and TGF- $\beta$, targeting cancer cells and the microenvironment, reduces bone metastasis by decreasing osteoclastic bone resorption and increasing osteoblast activity [148]. Extending these findings, the HIF- $1 \alpha$-mediated release of TGF- $\beta$ in hypoxic breast tumor microenvironment triggers Mesenchymal Stem Cells (MSCs) activation, thereby promoting growth, motility and invasive effects in breast cancer cells [149]. Of note, the tumor suppressor gene TAp73 elicits anti-cancer effects by simultaneously blocking HIF- $1 \alpha$ and the pro-inflammatory chemokines $\mathrm{Ccl} 2, \mathrm{Cxcl} 1, \mathrm{Cxcl} 2$, which are known to promote angiogenesis and leukocyte migration [150]. These observations support the idea of shared regulatory pathways that control both HIF- $1 \alpha$ and cytokine signaling in the tumor microenvironment, orchestrating paracrine interactions that facilitate tumor progression.

It's worth mentioning that cytokines produced within the breast tumor stroma promote cancer cell growth also by engaging the HIF- $1 \alpha /$ Notch signaling. For instance, using mammosphere assay as 
a readout for CSCs activity, Sanguinetti and coworkers found that IL-6 induces stem-like features by stimulating the Notch-3-dependent upregulation of the carbonic anhydrase IX gene and promoting a hypoxia-resistant/invasive phenotype in breast cancer cells [151]. In addition, IL-6 derived from metastatic CAFs triggered breast cancer growth in vitro and in vivo through the involvement of Notch-3, Jagged-1, and the HIF-1 $\alpha$ target gene carbonic anhydrase IX [152].

On the other hand, in the hypoxic breast tumor microenvironment, HIF- $1 \alpha$ triggers Notch-3 up-regulation toward the decrease of IL-6 levels and the inhibition of the CSCs population, whereas the gamma secretase inhibitors MK-0752 and RO4929097 increase the CSCs population in an IL-6 dependent manner [153]. These observations suggest that coupling Notch inhibitors with cytokine-disrupting agents may serve as effective therapeutic strategy for breast cancer patients, although the contribution of several microenvironmental factors, including local hypoxia, should also be considered. Based on these observations, the cross-talk between HIF- $1 \alpha$ and Notch signaling pathways may serve as a molecular bridge connecting together the multiple paracrine interactions occurring between breast cancer cells and CAFs toward disease progression.

\section{Hypoxia-Independent Activation of HIF-1 in Cancer and Stromal Cells}

Although both prolyl and asparaginyl hydroxylases represent canonical components of the $\mathrm{O}_{2}$-sensing cell machinery, HIF-1 $\alpha$ activation in cancer may rely on additional non-canonical pathways, including several $\mathrm{O}_{2}$-independent molecular mechanisms. In this context, loss of VHL expression or function, as well as activation of chaperones like RACK1, were shown to play an integral role [154-156]. Although modulation of HIF- $1 \alpha$ protein stability has been classically regarded as the main mechanism regulating HIF1 $\alpha$-dependent function, it is now evident that changes in HIF- $1 \alpha$ mRNA expression levels and induction of protein synthesis can be accountable for certain molecular and biological actions mediated by this transcription factor, particularly in breast cancer. Several extrinsic and intrinsic cues, including oncogene activation, growth factors, hypoxia, cytokines, $\mathrm{pH}$, and free radicals were shown to induce major pro-survival pathways, including the ERK/MAPK, JAK/STAT and $\mathrm{PI} 3 \mathrm{~K} / \mathrm{AKT} / \mathrm{mTOR}$ cascades, in turn regulating both HIF-1 $\alpha$ gene expression and protein translation, hence promoting tumor progression, invasion and therapeutic resistance $[157,158]$. In this regard, it should be mentioned that aberrant Receptor Tyrosine Kinase (RTK) signaling, which is frequently observed in human cancer, is at least in part responsible for the increased up-regulation of HIF-1 $\alpha$ mRNA and/or protein expression. For instance, EGFR and Her2 signaling have been shown to increase the rate of HIF- $1 \alpha$ synthesis and the subsequent expression of survivin and VEGF in breast cancer cells, through the involvement of the PI3k/AKT pathway and the downstream kinase FRAP (FKBP-rapamycin-associated protein) [159]. This study suggests that EGFR- and HER2-mediated induction of HIF- $1 \alpha$ expression may play a relevant role in breast tumor angiogenesis and progression. Of note, HIF- $1 \alpha$ expression in normoxic conditions was shown to mediate certain detrimental effects dependent on HER2 action and involved in the resistance to aromatase inhibitors in breast cancer cells [159].

Several lines of evidence have suggested that the IGF-IR/IR signaling is implicated in the activation of the HIF-1 $\alpha$ pathway in breast cancer. In ER-positive breast cancer cells, IGF-I was shown to induce HIF- $1 \alpha$ protein translation through the PI-3K/AKT/mTOR-pathway and promote its transcriptional activity, without affecting HIF-1 $\alpha$ mRNA levels $[160,161]$. On the other hand, in ER-negative breast cancer cells and CAFs, IGF-I up-regulated both HIF- $1 \alpha$ mRNA and protein levels through the activation of AKT and MAPK transduction pathways [162].

Recently, the chemotherapeutic agents, paclitaxel or gemcitabine, were shown to induce HIF-1 $\alpha$ transcriptional activation through elevation of ROS levels and in turn promote the chemo-resistance of breast cancer stem cells [163].

Elevation of ROS levels is crucial also for the copper-dependent induction of HIF- $1 \alpha$ expression in breast cancer cells [164]. In this study, we showed that the ROS scavenger NAC abrogated the effect of copper on the activation of the EGFR/ERK/c-fos transduction pathway leading to the expression 
of HIF- $1 \alpha$, GPER and VEGF in breast and hepatic cancer cells. Furthermore, we demonstrated that a functional cooperation between HIF-1 $\alpha$ and GPER contributes to VEGF regulation in cancer cells exposed to copper [164]. Further extending the cooperation between GPER and HIF- $1 \alpha$ in tumor progression and invasion, we reported that in normoxic breast cancer cells estrogen-activated GPER induces HIF-1 $\alpha$ expression and its target gene VEGF [165]. Furthermore GPER also mediated the effect of endothelin-1 (ET-1) on HIF-1 expression in normoxic ER negative breast cancer cells [166]. As discussed in the next section, the mechanism through which GPER signaling induces HIF-1 $\alpha$ expression remains to be elucidated, however our studies demonstrated that the cross-talk between GPER and the Epidermal Growth Factor Receptor (EGFR) signaling plays a relevant role in inducing HIF-1 $\alpha$ protein levels [165]. In this regard, in ER-negative breast cancer cells and CAFs, estrogenic GPER signaling was shown to activate EGFR/ERK transduction cascade, leading to the increase of c-fos [165], which is known to regulate gene transcription by binding to the AP1 consensus sequence in the promoter of target genes, together with members belonging to the c-jun family [167]. The GPER triggered EGFR/ERK/c-fos transduction pathway was shown to mediate the transcriptional up-regulation of HIF- $1 \alpha$ by estrogen, possibly activating the AP-1 sites within the HIF-1 $\alpha$ promoter [165]. Likewise, breast cancer cells engineered to overexpress a mutant c-fos, unable to bind the AP-1 sites, failed to induce the up-regulation of HIF- $1 \alpha$ in response to estrogen [165], thus supporting the involvement of the transcription factor c-fos in the transcriptional activation of HIF- $1 \alpha$ gene.

\section{HIF-1 $\alpha$ Regulation by E2 (ER e GPER)}

The bi-directional and reciprocal interplay between estrogen and hypoxia signaling has been shown to regulate a number of physio-pathological functions in cellular and animal models. For instance, in rat uterus both ER $\alpha$ and HIF- $1 \alpha$ were found to be recruited to the HRE consensus sequences located within the VEGF promoter upon stimulation with E2 during normoxia [168]. In addition, ER $\alpha$ mediates estrogenic regulation of HIF- $1 \alpha$ in ovarian and breast cancer cells, breast cancer associated fibroblasts and in the rat uterus [165,169-171]. On the other hand, HIFs appear to regulate the expression and functionality of ERs, including the classic ER $\alpha$ and $E R \beta$, as well as the alternate estrogen receptor GPER [172-174]. Corroborating the hypothesis of a complex molecular interdependence between ER- and HIF-mediated pathways, an increased expression of HIF- $1 \alpha$ has been correlated with a more aggressive phenotype in ER positive breast cancer [175]; furthermore HIF-1 $\beta$ serves as a potent coactivator of ER-mediated gene transcription [176]. Recently, a comprehensive overview of HIF- $1 \alpha$ action on ER $\alpha$ expression and function was provided in a selected panel of ER-positive breast cancer cells, which were representative of the diverse genetic backgrounds and mutational landscape commonly observed in ER- $\alpha$ positive tumors. Results from this investigation show that low environmental $\mathrm{O}_{2}$ triggers HIF- $1 \alpha$ activity toward a rapid reduction of ER $\alpha$ protein levels, due to enhanced proteolysis [172]. These data add to previous studies showing that in breast cancer cells as well as in human breast tumor samples HIF- $1 \alpha$ lowers ER $\alpha$ levels by repressing its transcription upon stimulation with hypoxia or hypoxia-mimetic agents [177-179]. Altogether these observations have profound clinical implications, as pharmacological strategies aimed at inhibiting HIF- $1 \alpha$ action and/or proteasomal degradation might represent useful strategies for stabilizing ER $\alpha$ expression and sensitize certain sub-populations of breast cancer patients to endocrine therapies [180].

Extending the framework of these findings, estrogens were reported to regulate HIF- $1 \alpha$ activity both in normoxic and hypoxic conditions in breast cancer. For instance, in normoxic conditions E2 led to the recruitment of ER $\alpha$ to VEGF promoter, hence inducing VEGF expression [181]. Differently, in hypoxic conditions VGEF expression was driven by ER-dependent recruitment of HIF- $1 \alpha$ to its promoter [181]. Of note, in human breast cancer cells, a rapid estrogen action involving ER $\alpha$-mediated activation of the c-Src/PI3K/AKT/mTOR pathway was accountable for the up-regulation of HIF-1 $\alpha$ protein expression [182].

On the other hand, HIFs-dependent effects can be differentially regulated in ER $\alpha$-positive compared to ER $\alpha$-negative breast tumors [183]. For instance, in ER $\alpha$-positive tumors hypoxia increased 
CSCs activity in an ER $\alpha$ /Notch-dependent fashion, whereas it decreased CSCs in ER- $\alpha$ negative context [183]. Furthermore, it has been elucidated that many of the HIF- $1 \alpha$ target genes bear both hypoxia- and estrogen-response elements, and are regulated by ER $\alpha$ in both normoxic and hypoxic conditions [184]. Completing this intricate puzzle, a functional ERE sequence was detected also within the HIF- $1 \alpha$ promoter [184]. Of note, in ER $\alpha$ breast tumor patients, a hypoxia metagene signature together with upregulated HIF- $1 \alpha$ expression were associated with lower response to endocrine treatment, corroborating the importance of ER $\alpha / \mathrm{HIF}-1 \alpha$ crosstalk in the hormone response to treatment [185].

Despite the stimulatory role mediated by E2/ER $\alpha$ signaling on HIF- $1 \alpha$ expression in breast cancer, the interaction between estrogen signaling and HIF- $2 \alpha$ shows an opposite trend. Indeed, E2 causes down-regulation of both HIF- $2 \alpha$ mRNA and protein expression in ER-positive breast cancer cells, but not in ER-negative cells. This negative regulation possibly involves an ER $\alpha$-mediated recruitment of co-repressors to the estrogen response element (ERE) of the HIF-2 $\alpha$ promoter [186].

It should be mentioned that ER $\beta$ has been associated with reduced HIF-1 transcriptional activity during hypoxia in the diverse cancer cell context, including breast cancer $[187,188]$. Nevertheless certain discrepancies on the role of ER $\beta$ in modulating HIF-1 activity are reported in the literature; for instance, ER $\beta$ was positively correlated with HIF- $1 \alpha$ in primary and metastatic breast tumors [189]. Furthermore, the human ER $\beta$ variant ER $\beta 2$ was negatively associated with PHD3, but positively associated with HIF-1 $\alpha$, toward aggressive features in triple negative breast cancer cells [190].

As discussed earlier in this review, beyond $E R \alpha$ and $E R \beta$, estrogens signal through the G-protein coupled estrogen receptor, a member belonging to the rhodopsine-like family of G-protein coupled receptors (GPCRs) [70]. As mentioned above, hypoxia is associated with both aggressive features of breast cancer and down-regulation of ER $\alpha$ pathway, suggesting that in low oxygen microenvironment estrogens might signal through GPER to overcome ER $\alpha$ loss. If so, GPER expression should be induced by hypoxia. Indeed, a bioinformatic analysis of the human GPER promoter has revealed HRE consensus sequences, suggesting that GPER might be regulated in hypoxic conditions in a HIF1 $\alpha$-dependent manner. This hypothesis was then verified in ER-negative breast cancer cells, where the exposure to low oxygen tension $\left(2 \% \mathrm{O}_{2}\right)$, as well as the treatment with the hypoxia mimetic $\mathrm{CoCl}_{2}$ triggered HIF- $1 \alpha$ accumulation and its recruitment to the GPER promoter, together with the subsequent up-regulation of GPER protein expression [174]. Interestingly, a functional cooperation between HIF- $1 \alpha$ and GPER in breast cancer cells and in breast cancer associated fibroblasts was shown to regulate the hypoxia-dependent VEGF expression toward tumor angiogenesis and progression [191]. Furthermore, hypoxia stimulates CAFs to secrete paracrine factors including IL-6, VEGF and CTGF, in a HIF-1 $\alpha$ /GPER dependent manner [192]. These observations suggest that GPER, similarly to ER $\alpha$, may serve as a further regulator of the hypoxic pathway through a functional crosstalk with HIF- $1 \alpha$.

As mentioned in the previous section, we found that estrogenic GPER signaling activated the HIF-1 $\alpha$ /VEGF transduction pathway in normoxic ER-negative breast cancer cells and CAFs, through the engagement of the EGFR/ERK/c-fos cascade [165]. This engagement of GPER was required for boosting new blood vessel formation and lead tumor growth in a mouse xenograft model of breast cancer [165].

These observations extend previous findings showing that hormones and growth factors may regulate HIF-1-dependent functions in normoxia through several mechanisms that include HIF-1 $\alpha$ gene transcription, protein translation, as well as protein stabilization [160,161]. Additional investigations should clarify whether the use of proteasome inhibitors may have a deeper impact on GPER-mediated HIF-1 $\alpha$ functions in normoxic conditions, evidencing whether HIF-1 protein stabilization rather than gene transcription might play a more relevant role in GPER action. Recently, Yu and collaborators demonstrated that GPER signaling triggers aerobic glycolysis in breast CAFs, leading to the accumulation of the end by-products pyruvate and lactate [193]. As these fuels may act as oncometabolites in cancer cells, it is conceivable to hypothesize that the $\mathrm{O}_{2}$-independent regulation of HIF- $1 \alpha$ by GPER may result from the activation of the glycolytic pathway and the subsequent 
production of pyruvate and lactate, which are known to stabilize HIF-1 $\alpha$ in normoxia [194-196], generating a condition known as pseudo-hypoxia [158].

Evidence for a stimulatory role exerted by E2-activated GPER on HIF-1 $\alpha$ expression was obtained also in certain physio-pathological conditions associated with de-regulated estrogen signaling as endometriosis [197]. Recently, $\mathrm{Xu}$ et al. demonstrated that in a hypoxic microenvironment, BPA promotes proliferative effects in both breast cancer cell and endothelial cells by inducing HIF- $1 \alpha$ and VEGF expressions in a GPER-mediated manner [198]. These data suggest that a molecular loop connecting HIF- $1 \alpha$ and GPER supports breast cancer progression in a multilayered fashion that includes components of both cancer and stromal cells. On the other hand, a tumor-suppressive role for the HIF-1 $\alpha$ /GPER signaling was demonstrated in certain sub-populations of breast cancer recapitulating the molecular features of the triple negative subtype. In this regard, in vitro and in vivo evidence showed that GPER blocks cell cycle progression, induces apoptosis, inhibits migration and invasion, and reverses the process of EMT in the context of TNBC (Triple Negative Breast Cancer) $[199,200]$. In addition, the selective activation of GPER by its synthetic ligand G-1 mediates anti-angiogenic effects by repressing the HIF-1 $\alpha$ /VEGF signaling in the triple negative MDA-MB-231 breast cancer cells [201], thus suggesting that the tumor promoting/tumor suppressive role of the HIF- $1 \alpha /$ GPER signaling in breast cancer may at least in part depend on the ER and HER2 status.

The translational implications of the interdependence between estrogenic and hypoxic signaling mediated by ER and/or GPER together with HIF-1 $\alpha$ could deeply impact the development of novel combination strategies aimed at inhibiting breast cancer progression and overcoming anti-cancer drug resistance. Further studies are required to better clarify the involvement of ERs and HIF- $1 \alpha$ cross-talk in the regulation of key events involved in breast metastasis and therapeutic escape. For instance, it has been reported that HIFs are involved in the establishment of both chemo- and endocrineresistance $[163,202]$ by facilitating the enrichment of breast cancer stem cells populations, regardless of ER status.

\section{Does a Signaling Network between Notch, HIF-1 $\alpha$, and GPER Strengthen EMT in Breast Cancer Cells?}

Besides conferring migratory and invasive features to epithelial cancer cells, the induction of cancer EMT is also linked to the gaining of other properties, including enhanced stem cell and chemotherapy resistance. The extent of these acquired cellular capabilities by cancer cells is dependent on the type and strength of the signal inducing EMT. In cancer EMT, signaling networks are of particular importance for the generation of robust cellular responses to microenvironmental variations. For example, the functional interplay of Notch signaling with hypoxia and TGF $\beta$ has been suggested to induce a more rapid and pronounced EMT in cancerous epithelial cells [52,203]. Individually, hypoxia and TGF $\beta$ signaling pathways have been shown to induce Notch-mediated EMT by different mechanisms that converge at the level of NICD [204]. Likely, if such signaling pathways are simultaneously active in the cell, they may result in a more robust EMT [203,204]. In breast cancer cells, the effect of hypoxia on Notch-mediated EMT is mediated by HIF- $1 \alpha$ recruitment at the Snail promoter, which in turn potentiates NICD/CSL/MAML-dependent expression of the Snail gene [38] (Figure 2). Similarly, estrogen/GPER signaling leads to the induction of Snail expression in a NICD/CSL/MAML-dependent manner [6], suggesting that GPER may cooperate with HIF-1 $\alpha$ to potentiate Notch-dependent expression of Snail in breast cancer cells exposed to both hypoxia and estrogen. Indeed, GPER was shown to cooperate with HIF-1 $\alpha$ for the expression of invasive markers, including CTGF, VEGF and IL- 6 in both breast cancer cells and CAFs exposed to low oxygen [191,192]. Interestingly, in CAFs derived from breast carcinomas, estrogen induces GPER translocation to the nucleus and its recruitment at promoters of genes involved in cell migration and angiogenesis $[78,174,191,205]$. In particular, it was shown that nuclear GPER potentiates HIF-1 $\alpha$ recruitment at the VEGF promoter, in turn increasing VEGF expression and activity [191]. Collectively, these observations suggest that estrogen could possibly strengthen Notch-mediated EMT by increasing 
HIF-1 $\alpha$ recruitment at the Snail promoter via nuclear GPER. On the other hand, studies in ER-negative breast cancer $\mathrm{SkBr} 3$ cells showed that estrogen/GPER signaling is able to induce HIF- $1 \alpha$ expression and activity [165] as well as Notch-1 mRNA levels and NICD accumulation [6], suggesting that estrogen/GPER may strengthen EMT by simultaneously inducing Notch and HIF-1 $\alpha$ signaling pathways in normoxic breast cancer cells (Figure 2). A further understanding of how hypoxia and estrogen converge on Notch signaling activation will provide further information on how intracellular signal networks mediate information from the cellular microenvironment to the cell nucleus to support a robust EMT in breast cancer cells.

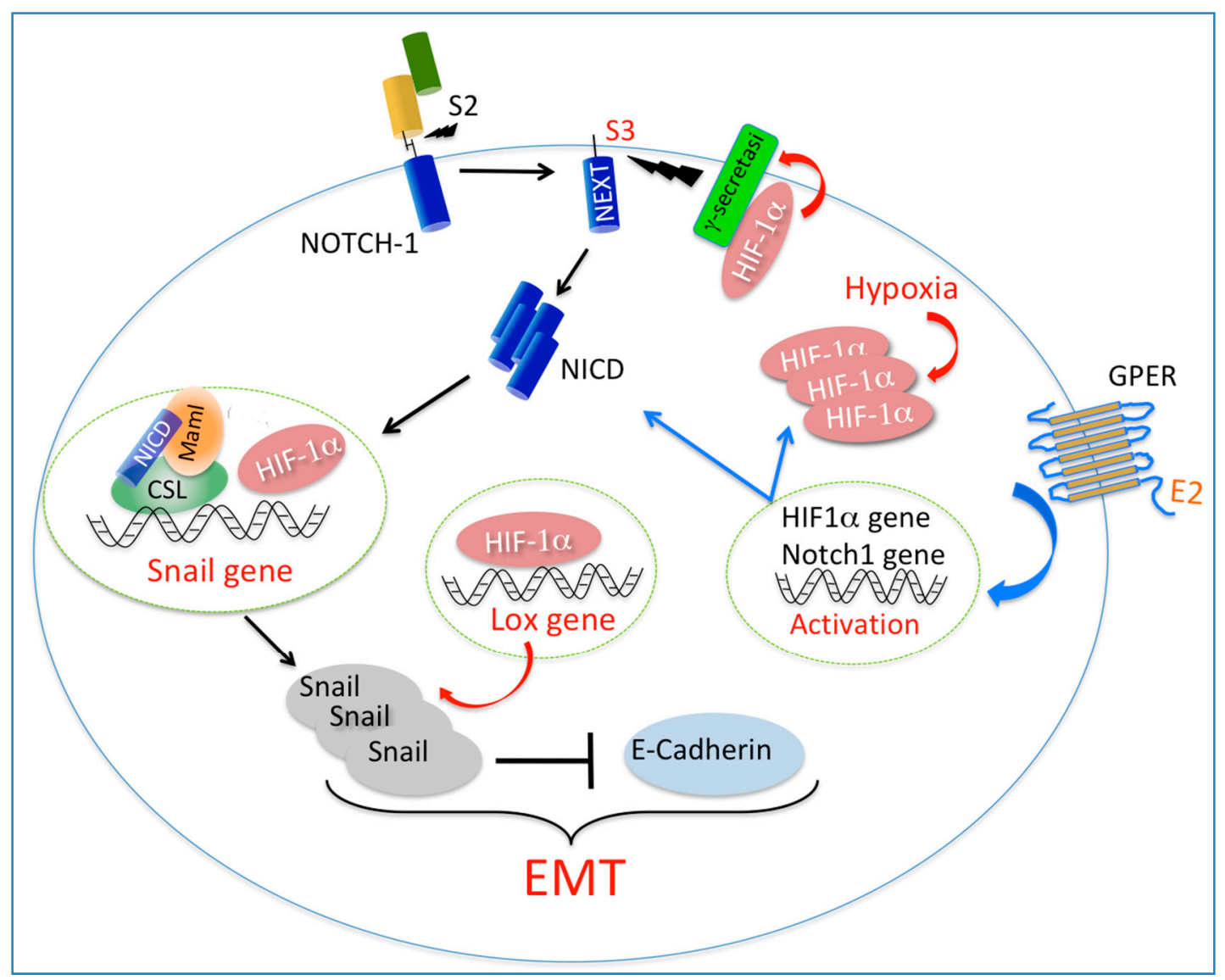

Figure 2. Proposed model for a signaling network between Notch, HIF- $1 \alpha$, and GPER in cancer epithelial-mesenchymal-transition (EMT). In hypoxic breast cancer cells, HIF- $1 \alpha$ accumulation increases $\gamma$-secretase activity and in turn NICD generation. In the nucleus, NICD and HIF- $1 \alpha$ cooperates for the induction of Snail gene expression. Also, HIF-1 $\alpha$ indirectly regulates Snail protein stability by inducing the expression of LOX gene. E2-activated GPER may potentiate the effect of hypoxia on Notch-dependent expression of Snail by directly inducing transcriptional activation of both Notch-1 and HIF-1 $\alpha$. In normoxic breast cancer cells, E2/GPER induces both Notch-1 expression and activation of the Notch core pathway, hence leading to the induction of Snail-1 expression. In addition, E2/GPER may potentiate Notch-dependent expression of Snail by inducing HIF-1 $\alpha$ expression and HIF-1 $\alpha$-dependent transcriptional activity. Red arrows indicate mechanisms shown in hypoxic cells; blue arrows indicate mechanisms shown in normoxic cells; black arrows indicate mechanisms shown in both normoxic and hypoxic cells.

\section{Therapeutic Approaches Targeting Notch Signaling in Breast Cancer}

The evidence that deregulation of the Notch signaling pathway favorites tumor growth and invasiveness has led to the development of various therapeutic approaches targeting different molecules along this pathway $[3,206]$. These include a variety of $\gamma$-secretase inhibitors (GSI) [206], 
antibodies against Notch1-3 receptors [207,208] or DLL4 ligand [209], Notch soluble decoys targeting Notch1, and DLL1 [210,211]. Other types of experimental inhibitors have been developed to inhibit the NICD transcriptional activation complex and consist of synthetic peptides or small inhibitor molecules blocking the interaction of MAML-1 with the NICD/CSL transcriptional complex [212,213]. Also, further small molecules targeting the Notch endocytic pathway have been screened and shown to inhibit endogenous Notch signaling in vitro and in vivo [214], or to selectively target the endocytic maturation of oncogenic Notch-1 mutations [215].

The interplay of the Notch signaling with several others context-specific tumorigenic pathways has prompted the usage of GSIs in combination therapies for different types of solid tumors [206]. Earlier studies in ER $\alpha$-positive breast cancer cells indicated that the combination of antiestrogen with GSI might be a potential therapeutic strategy in clinical studies [61]. Similarly, studies in breast tumor xenografts generated by ErbB-2 positive BTA474 breast cancer cells suggested that the combination of trastuzumab with GSI could decrease the recurrence of ErbB-2-positive breast tumors and may be beneficial in the treatment of recurrent trastuzumab-resistant disease [216]. Furthermore, both preclinical and clinical studies showed the combination of GSI with docetaxel targets breast cancer stem cells in human breast tumors [217]. Similarly, the combination of the reversal GSI inhibitor PF-03084014 with docetaxel inhibits tumor growth in patient-derived xenograft models of triple-negative breast cancer [218]. GSI also inhibits the tumorigenic effect of hypoxia in breast cancer progression and invasiveness [98], suggesting that it can potentially be used in combination with chemotherapy to prevent or delay the onset of metastatic breast malignancy.

In perspective, further identifications of context-specific Notch-interacting partners could be crucial for the development of more targeted antitumor therapy protocols with fewer side effects. In this regard, more insights into the signaling network between Notch, HIF- $1 \alpha$, and GPER in breast cancer EMT could provide new hints for the generation of novel combination strategies targeting breast cancer progression and overcoming anti-cancer drug resistance.

Author Contributions: A.M.M. contributed to the Sections concerning the Notch signaling pathway and its interaction with HIF-1 $\alpha$ and GPER signaling; E.M.D.F. and M.M. contributed to the Sections concerning Hypoxia signaling in breast cancer cells and HIF-1 $\alpha$ /GPER crosstalk in breast cancer cells and CAFs. All authors approved the submitted version of the manuscript and agree to be personally accountable for the author's own contributions and for ensuring that questions related to the accuracy or integrity of any part of the work, even ones in which the author was not personally involved, are appropriately documented in the literature. All authors declare that this manuscript has not been published and is not under consideration for publication elsewhere.

Acknowledgments: M.M. was supported by the Associazione Italiana per la Ricerca sul Cancro (AIRC, IG 16719); A.M.M was supported by the University of Calabria, Rende/Cs) Italy. E.M.D.F. was supported by a fellowship from the Associazione Italiana per la Ricerca sul Cancro (AIRC) co-funded by the European Union.

Conflicts of Interest: All authors declare that none of the authors have conflicts of interest to disclose.

\section{References}

1. Siebel, C.; Lendahl, U. Notch Signaling in Development, Tissue Homeostasis, and Disease. Physiol. Rev. 2017, 97, 1235-1294. [CrossRef] [PubMed]

2. Ranganathan, P.; Weaver, K.L.; Capobianco, A.J. Notch signalling in solid tumours: A little bit of everything but not all the time. Nat. Rev. Cancer 2011, 11, 338-351. [CrossRef] [PubMed]

3. Ntziachristos, P.; Lim, J.S.; Sage, J.; Aifantis, I. From fly wings to targeted cancer therapies: A centennial for notch signaling. Cancer Cell 2014, 25, 318-334. [CrossRef] [PubMed]

4. Kopan, R.; Ilagan, M.X. The canonical Notch signaling pathway: Unfolding the activation mechanism. Cell 2009, 137, 216-233. [CrossRef] [PubMed]

5. Palmer, W.H.; Deng, W.M. Ligand-Independent Mechanisms of Notch Activity. Trends Cell Biol. 2015, 25, 697-707. [CrossRef] [PubMed]

6. Pupo, M.; Pisano, A.; Abonante, S.; Maggiolini, M.; Musti, A.M. GPER activates Notch signaling in breast cancer cells and cancer-associated fibroblasts (CAFs). Int. J. Biochem. Cell Biol. 2014, 46, 56-67. [CrossRef] [PubMed] 
7. Landor, S.K.; Lendahl, U. The interplay between the cellular hypoxic response and Notch signaling. Exp. Cell Res. 2017, 356, 146-151. [CrossRef] [PubMed]

8. Bray, S.J. Notch signalling in context. Nat. Rev. Mol. Cell Biol. 2016, 17, 722-735. [CrossRef] [PubMed]

9. Nam, Y.; Weng, A.P.; Aster, J.C.; Blacklow, S.C. Structural requirements for assembly of the CSL.intracellular Notch1.Mastermind-like 1 transcriptional activation complex. J. Biol. Chem. 2003, 278, 21232-21239. [CrossRef] [PubMed]

10. Bray, S.J.; Gomez-Lamarca, M. Notch after cleavage. Curr. Opin. Cell Biol. 2018, 51, 103-109. [CrossRef] [PubMed]

11. Giaimo, B.D.; Oswald, F.; Borggrefe, T. Dynamic chromatin regulation at Notch target genes. Transcription 2017, 8, 61-66. [CrossRef] [PubMed]

12. Gomez-Lamarca, M.J.; Falo-Sanjuan, J.; Stojnic, R.; Abdul Rehman, S.; Muresan, L.; Jones, M.L.; Pillidge, Z.; Cerda-Moya, G.; Yuan, Z.; Baloul, S.; et al. Activation of the Notch Signaling Pathway In Vivo Elicits Changes in CSL. Nucl. Dyn. Dev. Cell 2018, 44, 611-623.e7. [CrossRef] [PubMed]

13. Vaccari, T.; Lu, H.; Kanwar, R.; Fortini, M.E.; Bilder, D. Endosomal entry regulates Notch receptor activation in Drosophila melanogaster. J. Cell Biol. 2008, 180, 755-762. [CrossRef] [PubMed]

14. Baron, M. Endocytic routes to Notch activation. Semin. Cell Dev. Biol. 2012, 23, 437-442. [CrossRef] [PubMed]

15. Gupta-Rossi, N.; Six, E.; LeBail, O.; Logeat, F.; Chastagner, P.; Olry, A.; Israël, A.; Brou, C. Monoubiquitination and endocytosis direct gamma-secretase cleavage of activated Notch receptor. J. Cell Biol. 2004, 166, 73-83. [CrossRef] [PubMed]

16. Andersson, E.R.; Sandberg, R.; Lendahl, U. Notch signaling: Simplicity in design, versatility in function. Development 2011, 138, 3593-3612. [CrossRef] [PubMed]

17. Moretti, J.; Chastagner, P.; Gastaldello, S.; Heuss, S.F.; Dirac, A.M.; Bernards, R.; Masucci, M.G.; Israël, A.; Brou, C. The translation initiation factor $3 \mathrm{f}$ (eIF3f) exhibits a deubiquitinase activity regulating Notch activation. PLoS Biol. 2010, 8, e1000545. [CrossRef] [PubMed]

18. Gulino, A.; Di Marcotullio, L.; Screpanti, I. The multiple functions of Numb. Exp. Cell Res. 2010, 316, 900-906. [CrossRef] [PubMed]

19. Yan, B. Numb-From flies to humans. Brain Dev. 2010, 32, 293-298. [CrossRef] [PubMed]

20. Chastagner, P.; Israël, A.; Brou, C. AIP4/Itch regulates Notch receptor degradation in the absence of ligand. PLoS ONE 2008, 16, e2735. [CrossRef] [PubMed]

21. Wilkin, M.B.; Carbery, A.M.; Fostier, M.; Aslam, H.; Mazaleyrat, S.L.; Higgs, J.; Myat, A.; Evans, D.A.; Cornell, M.; Baron, M. Regulation of notch endosomal sorting and signaling by Drosophila Nedd4 family proteins. Curr. Biol. 2004, 14, 2237-2244. [CrossRef] [PubMed]

22. Vaccari, T.; Bilder, D. The Drosophila tumor suppressor vps 25 prevents nonautonomous overproliferation by regulating notch trafficking. Dev. Cell 2005, 9, 687-698. [CrossRef] [PubMed]

23. Thompson, B.J.; Mathieu, J.; Sung, H.H.; Loeser, E.; Rørth, P.; Cohen, S.M. Tumor suppressor properties of the ESCRT-II complex component Vps25 in Drosophila. Dev. Cell 2005, 9, 711-720. [CrossRef] [PubMed]

24. Childress, J.L.; Acar, M.; Tao, C.; Halder, G. Lethal giant discs, a novel C2-domain protein, restricts notch activation during endocytosis. Curr. Biol. 2006, 16, 2228-2233. [CrossRef] [PubMed]

25. Mukherjee, T.; Kim, W.S.; Mandal, L.; Banerjee, U. Interaction between Notch and Hif-alpha in development and survival of Drosophila blood cells. Science 2011, 332, 1210-1213. [CrossRef] [PubMed]

26. Wang, Y.; Roche, O.; Yan, M.S.; Finak, G.; Evans, A.J.; Metcalf, J.L.; Hast, B.E.; Hanna, S.C.; Wondergem, B.; Furge, K.A.; et al. Regulation of endocytosis via the oxygen-sensing pathway. Nat. Med. 2009, 15, 319-324. [CrossRef] [PubMed]

27. Tagami, S.; Okochi, M.; Yanagida, K.; Ikuta, A.; Fukumori, A.; Matsumoto, N.; Ishizuka-Katsura, Y.; Nakayama, T.; Itoh, N.; Jiang, J.; et al. Regulation of Notch signaling by dynamic changes in the precision of S3 cleavage of Notch-1. Mol. Cell. Biol. 2008, 28, 165-176. [CrossRef] [PubMed]

28. Kobia, F.; Duchi, S.; Deflorian, G.; Vaccari, T. Pharmacologic inhibition of vacuolar H+ ATPase reduces physiologic and oncogenic Notch signaling. Mol. Oncol. 2014, 8, 207-220. [CrossRef] [PubMed]

29. Robinson, D.R.; Kalyana-Sundaram, S.; Wu, Y.M.; Shankar, S.; Cao, X.; Ateeq, B.; Asangani, I.A.; Iyer, M.; Maher, C.A.; Grasso, C.S.; et al. Functionally recurrent rearrangements of the MAST kinase and Notch gene families in breast cancer. Nat. Med. 2011, 17, 1646-1651. [CrossRef] [PubMed]

30. Guruharsha, K.G.; Kankel, M.W.; Artavanis-Tsakonas, S. The Notch signalling system: Recent insights into the complexity of a conserved pathway. Nat. Rev. Genet. 2012, 13, 654-666. [CrossRef] [PubMed] 
31. Moretti, J.; Brou, C. Ubiquitinations in the notch signaling pathway. Int. J. Mol. Sci. 2013, 19, 6359-6381. [CrossRef] [PubMed]

32. Yumimoto, K.; Akiyoshi, S.; Ueo, H.; Sagara, Y.; Onoyama, I.; Ueo, H.; Ohno, S.; Mori, M.; Mimori, K.; Nakayama, K.I. F-box protein FBXW7 inhibits cancer metastasis in a non-cell-autonomous manner. J. Clin. Investig. 2015, 125, 621-635. [CrossRef] [PubMed]

33. Shimizu, K.; Nihira, N.T.; Inuzuka, H.; Wei, W. Physiological functions of FBW7 in cancer and metabolism. Cell. Signal. 2018, 46, 15-22. [CrossRef] [PubMed]

34. Anzi, S.; Finkin, S.; Shaulian, E. Transcriptional repression of c-Jun's E3 ubiquitin ligases contributes to c-Jun induction by UV. Cell. Signal. 2008, 20, 862-871. [CrossRef] [PubMed]

35. Liu, Z.; Brunskill, E.; Varnum-Finney, B.; Zhang, C.; Zhang, A.; Jay, P.Y.; Bernstein, I.; Morimoto, M.; Kopan, R. The intracellular domains of Notch1 and Notch2 are functionally equivalent during development and carcinogenesis. Development 2015, 142, 2452-2463. [CrossRef] [PubMed]

36. Skalska, L.; Stojnic, R.; Li, J.; Fischer, B.; Cerda-Moya, G.; Sakai, H.; Tajbakhsh, S.; Russell, S.; Adryan, B.; Bray, S.J. Chromatin signatures at Notch-regulated enhancers reveal large-scale changes in H3K56ac upon activation. EMBO J. 2015, 34, 1889-1904. [CrossRef] [PubMed]

37. Wang, H.; Zang, C.; Taing, L.; Arnett, K.L.; Wong, Y.J.; Pear, W.S.; Blacklow, S.C.; Liu, X.S.; Aster, J.C. NOTCH1-RBPJ complexes drive target gene expression through dynamic interactions with superenhancers. Proc. Natl. Acad. Sci. USA 2014, 111, 705-710. [CrossRef] [PubMed]

38. Sahlgren, C.; Gustafsson, M.V.; Jin, S.; Poellinger, L.; Lendahl, U. Notch signaling mediates hypoxia-induced tumor cell migration and invasion. Proc. Natl. Acad. Sci. USA 2008, 29, 6392-6397. [CrossRef] [PubMed]

39. Yamamizu, K.; Matsunaga, T.; Uosaki, H.; Fukushima, H.; Katayama, S.; Hiraoka-Kanie, M.; Mitani, K.; Yamashita, J.K. Convergence of Notch and beta-catenin signaling induces arterial fate in vascular progenitors. J. Cell. Biol. 2010, 189, 325-338. [CrossRef] [PubMed]

40. Geudens, I.; Gerhardt, H. Coordinating cell behaviour during blood vessel formation. Development 2011, 138, 4569-4583. [CrossRef] [PubMed]

41. Liu, Z.; Fan, F.; Wang, A.; Zheng, S.; Lu, Y. Dll4-Notch signaling in regulation of tumor angiogenesis. J. Cancer Res. Clin. Oncol. 2014, 140, 525-536. [CrossRef] [PubMed]

42. Bridges, E.; Oon, C.E.; Harris, A. Notch regulation of tumor angiogenesis. Future Oncol. 2011, 7, 569-788. [CrossRef] [PubMed]

43. Boareto, M.; Jolly, M.K.; Ben-Jacob, E.; Onuchic, J.N. Jagged mediates differences in normal and tumor angiogenesis by affecting tip-stalk fate decision. Proc. Natl. Acad. Sci. USA 2015, 112, E3836-E3844. [CrossRef] [PubMed]

44. Kuhnert, F.; Chen, G.; Coetzee, S.; Thambi, N.; Hickey, C.; Shan, J.; Kovalenko, P.; Noguera-Troise, I.; Smith, E.; Fairhurst, J.; et al. Dll4 Blockade in Stromal Cells Mediates Antitumor Effects in Preclinical Models of Ovarian Cancer. Cancer Res. 2015, 75, 4086-4096. [CrossRef] [PubMed]

45. Noguera-Troise, I.; Daly, C.; Papadopoulos, N.J.; Coetzee, S.; Boland, P.; Gale, N.W.; Lin, H.C.; Yancopoulos, G.D.; Thurston, G. Blockade of Dll4 inhibits tumour growth by promoting non-productive angiogenesis. Nature 2006, 444, 1032-1037. [CrossRef] [PubMed]

46. Cao, Z.; Ding, B.S.; Guo, P.; Lee, S.B.; Butler, J.M.; Casey, S.C.; Simons, M.; Tam, W.; Felsher, D.W.; Shido, K.; et al. Angiocrine factors deployed by tumor vascular niche induce B cell lymphoma invasiveness and chemoresistance. Cancer Cell 2014, 25, 350-365. [CrossRef] [PubMed]

47. Lu, J.; Ye, X.; Fan, F.; Xia, L.; Bhattacharya, R.; Bellister, S.; Tozzi, F.; Sceusi, E.; Zhou, Y.; Tachibana, I.; et al. Endothelial cells promote the colorectal cancer stem cell phenotype through a soluble form of Jagged-1. Cancer Cell 2013, 23, 171-185. [CrossRef] [PubMed]

48. Thiery, J.P.; Acloque, H.; Huang, R.Y.; Nieto, M.A. Epithelial-mesenchymal transitions in development and disease. Cell 2009, 139, 871-890. [CrossRef] [PubMed]

49. Nieto, M.A.; Huang, R.Y.; Jackson, R.A.; Thiery, J.P. EMT: 2016. Cell 2016, 166, 21-45. [CrossRef] [PubMed]

50. Wang, Y.; Shi, J.; Chai, K.; Ying, X.; Zhou, B.P. The Role of Snail in EMT and Tumorigenesis. Curr. Cancer Drug Targets 2013, 13, 963-972. [CrossRef] [PubMed]

51. Zhou, J.; Jain, S.; Azad, A.K.; Xu, X.; Yu, H.C.; Xu, Z.; Godbout, R.; Fu, Y. Notch and TGF $\beta$ form a positive regulatory loop and regulate EMT in epithelial ovarian cancer cells. Cell. Signal. 2016, 28, 838-849. [CrossRef] [PubMed] 
52. Matsuno, Y.; Coelho, A.L.; Jarai, G.; Westwick, J.; Hogaboam, C.M. Notch signaling mediates TGF- $\beta 1$-induced epithelial-mesenchymal transition through the induction of Snai1. Int. J. Biochem. Cell Biol. 2012, 44, 776-789. [CrossRef] [PubMed]

53. Peinado, H.; Ballestar, E.; Esteller, M.; Cano, A. Snail mediates E-cadherin repression by the recruitment of the Sin3A/histone deacetylase 1 (HDAC1)/HDAC2 complex. Mol. Cell. Biol. 2004, 24, 306-319. [CrossRef] [PubMed]

54. Herranz, N.; Pasini, D.; Díaz, V.M.; Francí, C.; Gutierrez, A.; Dave, N.; Escrivà, M.; Hernandez-Muñoz, I.; Di Croce, L.; Helin, K.; et al. Polycomb complex 2 is required for E-cadherin repression by the Snail1 transcription factor. Mol. Cell. Biol. 2008, 28, 4772-4781. [CrossRef] [PubMed]

55. Lin, Y.; Wu, Y.; Li, J.; Dong, C.; Ye, X.; Chi, Y.I.; Evers, B.M.; Zhou, B.P. The SNAG domain of Snail1 functions as a molecular hook for recruiting lysine-specific demethylase 1. EMBO J. 2010, 29, 1803-1816. [CrossRef] [PubMed]

56. Li, Y.; Ma, J.; Qian, X.; Wu, Q.; Xia, J.; Miele, L.; Sarkar, F.H.; Wang, Z. Regulation of EMT by Notch signaling pathway in tumor progression. Curr. Cancer Drug Targets 2013, 13, 957-962. [CrossRef] [PubMed]

57. Fujiki, K.; Inamura, H.; Miyayama, T.; Matsuoka, M. Involvement of Notch1 signaling in malignant progression of A549 cells subjected to prolonged cadmium exposure. J. Biol. Chem. 2017, 292, 7942-7953. [CrossRef] [PubMed]

58. Reedijk, M.; Odorcic, S.; Chang, L.; Zhang, H.; Miller, N.; McCready, D.R.; Lockwood, G.; Egan, S.E. High-level coexpression of JAG1 and NOTCH1 is observed in human breast cancer and is associated with poor overall survival. Cancer Res. 2005, 65, 8530-8537. [CrossRef] [PubMed]

59. Stylianou, S.; Clarke, R.B.; Brennan, K. Aberrant activation of notch signaling in human breast cancer. Cancer Res. 2006, 66, 1517-1525. [CrossRef] [PubMed]

60. Heldring, N.; Pike, A.; Andersson, S.; Matthews, J.; Cheng, G.; Hartman, J.; Tujague, M.; Ström, A.; Treuter, E.; Warner, M.; et al. Estrogen receptors: How do they signal and what are their targets. Physiol. Rev. 2007, 87, 905-931. [CrossRef] [PubMed]

61. Rizzo, P.; Miao, H.; D’Souza, G.; Osipo, C.; Song, L.L.; Yun, J.; Zhao, H.; Mascarenhas, J.; Wyatt, D.; Antico, G.; et al. Cross-talk between notch and the estrogen receptor in breast cancer suggests novel therapeutic approaches. Cancer Res. 2008, 68, 5226-5235. [CrossRef] [PubMed]

62. Haughian, J.M.; Pinto, M.P.; Harrell, J.C.; Bliesner, B.S.; Joensuu, K.M.; Dye, W.W.; Sartorius, C.A.; Tan, A.C.; Heikkilä, P.; Perou, C.M.; et al. Maintenance of hormone responsiveness in luminal breast cancers by suppression of Notch. Proc. Natl. Acad. Sci. USA 2012, 109, 2742-2747. [CrossRef] [PubMed]

63. Stinson, S.; Lackner, M.R.; Adai, A.T.; Yu, N.; Kim, H.J.; O’Brien, C.; Spoerke, J.; Jhunjhunwala, S.; Boyd, Z.; Januario, T.; et al. TRPS1 targeting by miR-221/222 promotes the epithelial-to-mesenchymal transition in breast cancer. Sci. Signal. 2011, 4, ra41. [CrossRef] [PubMed]

64. Momeni, P.; Glöckner, G.; Schmidt, O.; von Holtum, D.; Albrecht, B.; Gillessen-Kaesbach, G.; Hennekam, R.; Meinecke, P.; Zabel, B.; Rosenthal, A.; et al. Mutations in a new gene, encoding a zinc-finger protein, cause tricho-rhino-phalangeal syndrome type I. Nat. Genet. 2000, 24, 71-74. [CrossRef] [PubMed]

65. Golan, T.; Messer, A.R.; Amitai-Lange, A.; Melamed, Z.; Ohana, R.; Bell, R.E.; Kapitansky, O.; Lerman, G.; Greenberger, S.; Khaled, M.; et al. Interactions of Melanoma Cells with Distal Keratinocytes Trigger Metastasis via Notch Signaling Inhibition of MITF. Mol. Cell 2015, 59, 664-676. [CrossRef] [PubMed]

66. Han, S.H.; Kim, H.J.; Gwak, J.M.; Kim, M.; Chung, Y.R.; Park, S.Y. MicroRNA-222 Expression as a Predictive Marker for Tumor Progression in Hormone Receptor-Positive Breast Cancer. J. Breast Cancer 2017, 20, 35-44. [CrossRef] [PubMed]

67. Fujita, N.; Jaye, D.L.; Kajita, M.; Geigerman, C.; Moreno, C.S.; Wade, P.A. MTA3, a Mi-2/NuRD complex subunit, regulates an invasive growth pathway in breast cancer. Cell 2003, 113, 207-219. [CrossRef]

68. Dhasarathy, A.; Kajita, M.; Wade, P.A. The transcription factor snail mediates epithelial to mesenchymal transitions by repression of estrogen receptor-alpha. Mol. Endocrinol. 2007, 21, 2907-2918. [CrossRef] [PubMed]

69. Bai, J.W.; Chen, M.N.; Wei, X.L.; Li, Y.C.; Lin, H.Y.; Chen, M.; Li, J.W.; Du, C.W.; Man, K.; Zhang, G.J. The zinc-finger transcriptional factor Slug transcriptionally downregulates ER $\alpha$ by recruiting lysine-specific demethylase 1 in human breast cancer. Oncogenesis 2017, 6, e330. [CrossRef] [PubMed] 
70. Barton, M.; Filardo, E.J.; Lolait, S.J.; Thomas, P.; Maggiolini, M.; Prossnitz, E.R. Twenty years of the G protein-coupled estrogen receptor GPER: Historical and personal perspectives. J. Steroid. Biochem. Mol. Biol. 2018, 176, 14-15. [CrossRef] [PubMed]

71. Filardo, E.J.; Graeber, C.T.; Quinn, J.A.; Resnick, M.B.; Giri, D.; DeLellis, R.A.; Steinhoff, M.M.; Sabo, E. Distribution of GPR30, a seven membrane-spanning estrogen receptor, in primary breast cancer and its association with clinicopathologic determinants of tumor progression. Clin. Cancer Res. 2006, 12, 6359-6366. [CrossRef] [PubMed]

72. Smith, H.O.; Leslie, K.K.; Singh, M.; Qualls, C.R.; Revankar, M.; Joste, N.E.; Prossnitz, E.R. GPR30: A novel indicator of poor survival for endometrial carcinoma. Am. J. Obstet. Gynecol. 2007, 196, 386.e1-386.e11. [CrossRef] [PubMed]

73. Smith, H.O.; Arias-Pulido, H.; Kuo, D.Y.; Howard, T.; Qualls, C.R.; Lee, S.J.; Verschraegen, C.F.; Hathaway, H.J.; Joste, N.E.; Prossnitz, E.R. GPR30 predicts poor survival for ovarian cancer. Gynecol. Oncol. 2009, 114, 465-471.

74. Sjöström, M.; Hartman, L.; Grabau, D.; Fornander, T.; Malmström, P.; Nordenskjöld, B.; Sgroi, D.C.; Skoog, L.; Stål, O.; Leeb-Lundberg, L.M.; et al. Lack of G protein-coupled estrogen receptor (GPER) in the plasma membrane is associated with excellent long-term prognosis in breast cancer. Breast Cancer Res. Treat. 2014, 145, 61-71. [CrossRef] [PubMed]

75. Zhou, C.; Zhong, Q.; Rhodes, L.V.; Townley, I.; Bratton, M.R.; Zhang, Q.; Martin, E.C.; Elliott, S.; Collins-Burow, B.M.; Burow, M.E.; et al. Proteomic analysis of acquired tamoxifen resistance in MCF-7 cells reveals expression signatures associated with enhanced migration. Breast Cancer Res. 2012, $14, \mathrm{R} 45$. [CrossRef] [PubMed]

76. Lappano, R.; Pisano, A.; Maggiolini, M. GPER Function in Breast Cancer: An Overview. Front. Endocrinol. 2014, 5, 66. [CrossRef] [PubMed]

77. Lappano, R.; Maggiolini, M. GPER is involved in the functional liaison between breast tumor cells and cancer-associated fibroblasts (CAFs). J. Steroid Biochem. Mol. Biol. 2018, 176, 49-56. [CrossRef] [PubMed]

78. Madeo, A.; Maggiolini, M. Nuclear alternate estrogen receptor GPR30 mediates 17beta-estradiol-induced gene expression and migration in breast cancer-associated fibroblasts. Cancer Res. 2010, 70, 6036-6046. [CrossRef] [PubMed]

79. Pandey, D.P.; Lappano, R.; Albanito, L.; Madeo, A.; Maggiolini, M.; Picard, D. Estrogenic GPR30 signalling induces proliferation and migration of breast cancer cells through CTGF. EMBO J. 2009, 28, 523-532. [CrossRef] [PubMed]

80. Jiang, Q.F.; Wu, T.T.; Yang, J.Y.; Dong, C.R.; Wang, N.; Liu, X.H.; Liu, Z.M. 17ß-estradiol promotes the invasion and migration of nuclear estrogen receptor-negative breast cancer cells through cross-talk between GPER1 and CXCR1. J. Steroid Biochem. Mol. Biol. 2013, 138, 314-324. [CrossRef] [PubMed]

81. Zhou, X.; Wang, S.; Wang, Z.; Feng, X.; Liu, P.; Lv, X.B.; Li, F.; Yu, F.X.; Sun, Y.; Yuan, H.; et al. Estrogen regulates Hippo signaling via GPER in breast cancer. J. Clin. Investig. 2015, 125, 2123-2135. [CrossRef] [PubMed]

82. De Marco, P.; Lappano, R.; De Francesco, E.M.; Cirillo, F.; Pupo, M.; Avino, S.; Vivacqua, A.; Abonante, S.; Picard, D.; Maggiolini, M. GPER signalling in both cancer-associated fibroblasts and breast cancer cells mediates a feedforward IL1 $\beta /$ IL1R1 response. Sci. Rep. 2016, 6, 24354. [CrossRef] [PubMed]

83. Semenza, G.L. Angiogenesis in ischemic and neoplastic disorders. Annu. Rev. Med. 2003, 54, 17-28. [CrossRef] [PubMed]

84. Semenza, G.L.; Roth, P.H.; Fang, H.M.; Wang, G.L. Transcriptional regulation of genes encoding glycolytic enzymes by hypoxia-inducible factor 1. J. Biol. Chem. 1994, 269, 23757-23763. [PubMed]

85. Simon, M.C.; Keith, B. The role of oxygen availability in embryonic development and stem cell function. Nat. Rev. Mol. Cell Biol. 2008, 9, 285-296. [CrossRef] [PubMed]

86. Peng, G.; Liu, Y. Hypoxia-inducible factors in cancer stem cells and inflammation. Trends Pharmacol. Sci. 2015, 36, 374-383. [CrossRef] [PubMed]

87. Hansson, E.M.; Lendahl, U.; Chapman, G. Notch signaling in development and disease. Semin. Cancer Biol. 2004, 14, 320-328. [CrossRef] [PubMed]

88. Gustafsson, M.V.; Zheng, X.; Pereira, T.; Gradin, K.; Jin, S.; Lundkvist, J.; Ruas, J.L.; Poellinger, L.; Lendahl, U.; Bondesson, M. Hypoxia requires notch signaling to maintain the undifferentiated cell state. Dev. Cell 2005, 9, 617-628. [CrossRef] [PubMed] 
89. Jögi, A.; Øra, I.; Nilsson, H.; Lindeheim, A.; Makino, Y.; Poellinger, L.; Axelson, H.; Påhlman, S. Hypoxia alters gene expression in human neuroblastoma cells toward an immature and neural crest-like phenotype. Proc. Natl. Acad. Sci. USA 2002, 99, 7021-7026. [CrossRef] [PubMed]

90. Irshad, K.; Mohapatra, S.K.; Srivastava, C.; Garg, H.; Mishra, S.; Dikshit, B.; Sarkar, C.; Gupta, D.; Chandra, P.S.; Chattopadhyay, P.; et al. A combined gene signature of hypoxia and notch pathway in human glioblastoma and its prognostic relevance. PLoS ONE 2015, 10, e0118201. [CrossRef] [PubMed]

91. Bao, B.; Azmi, A.S.; Ali, S.; Ahmad, A.; Li, Y.; Banerjee, S.; Kong, D.; Sarkar, F.H. The biological kinship of hypoxia with CSC and EMT and their relationship with deregulated expression of miRNAs and tumor aggressiveness. Biochim. Biophys. Acta 2012, 1826, 272-296. [CrossRef] [PubMed]

92. Imai, T.; Horiuchi, A.; Wang, C.; Oka, K.; Ohira, S.; Nikaido, T.; Konishi, I. Hypoxia attenuates the expression of E-cadherin via up-regulation of SNAIL in ovarian carcinoma cells. Am. J. Pathol. 2003, 163, 1437-1447. [CrossRef]

93. Choi, B.J.; Park, S.A.; Lee, S.Y.; Cha, Y.N.; Surh, Y.J. Hypoxia induces epithelial-mesenchymal transition in colorectal cancer cells through ubiquitin-specific protease 47-mediated stabilization of Snail: A potential role of Sox9. Sci. Rep. 2017, 7, 15918. [CrossRef] [PubMed]

94. Chen, J.; Imanaka, N.; Chen, J.; Griffin, J.D. Hypoxia potentiates Notch signaling in breast cancer leading to decreased E-cadherin expression and increased cell migration and invasion. Br. J. Cancer 2010, 102, 351-360. [CrossRef] [PubMed]

95. Ishida, T.; Hijioka, H.; Kume, K.; Miyawaki, A.; Nakamura, N. Notch signaling induces EMT in OSCC cell lines in a hypoxic environment. Oncol. Lett. 2013, 6, 1201-1206. [CrossRef] [PubMed]

96. De Craene, B.; Berx, G. Regulatory networks defining EMT during cancer initiation and progression. Nat. Rev. Cancer 2013, 13, 97-110. [CrossRef] [PubMed]

97. Wu, M.Z.; Tsai, Y.P.; Yang, M.H.; Huang, C.H.; Chang, S.Y.; Chang, C.C.; Teng, S.C.; Wu, K.J. Interplay between HDAC3 and WDR5 is essential for hypoxia-induced epithelial-mesenchymal transition. Mol. Cell 2011, 43, 811-822. [CrossRef] [PubMed]

98. Villa, J.C.; Chiu, D.; Brandes, A.H.; Escorcia, F.E.; Villa, C.H.; Maguire, W.F.; Hu, C.J.; de Stanchina, E.; Simon, M.C.; Sisodia, S.S.; et al. Nontranscriptional role of Hif- $1 \alpha$ in activation of $\gamma$-secretase and notch signaling in breast cancer. Cell. Rep. 2014, 8, 1077-1092. [CrossRef] [PubMed]

99. Brown, J.M.; Giaccia, A.J. The unique physiology of solid tumors: Opportunities (and problems) for cancer therapy. Cancer Res. 1998, 58, 1408-1416. [PubMed]

100. Hanahan, D.; Weinberg, R.A. Hallmarks of cancer: The next generation. Cell 2011, 4, 646-674. [CrossRef] [PubMed]

101. Muz, B.; de la Puente, P.; Azab, F.; Azab, A.K. The role of hypoxia in cancer progression, angiogenesis, metastasis, and resistance to therapy. Hypoxia 2015, 3, 83-92. [CrossRef] [PubMed]

102. Paolicchi, E.; Gemignani, F.; Krstic-Demonacos, M.; Dedhar, S.; Mutti, L.; Landi, S. Targeting hypoxic response for cancer therapy. Oncotarget 2016, 7, 13464-13478. [CrossRef] [PubMed]

103. Wigerup, C.; Påhlman, S.; Bexell, D. Therapeutic targeting of hypoxia and hypoxia-inducible factors in cancer. Pharmacol. Ther. 2016, 164, 152-169. [CrossRef] [PubMed]

104. Rundqvist, H.; Johnson, R.S. Tumour oxygenation: Implications for breast cancer prognosis. J. Intern. Med. 2013, 274, 105-112. [CrossRef] [PubMed]

105. Masoud, G.N.; Li, W. HIF-1 $\alpha$ pathway: Role, regulation and intervention for cancer therapy. Acta Pharm. Sin. B 2015, 5, 378-389. [CrossRef] [PubMed]

106. Gilkes, D.M.; Semenza, G.L. Role of hypoxia-inducible factors in breast cancer metastasis. Future Oncol. 2013, 9, 1623-1636. [CrossRef] [PubMed]

107. Schito, L.; Semenza, G.L. Hypoxia-Inducible Factors: Master Regulators of Cancer Progression. Trends Cancer 2016, 2, 758-770. [CrossRef] [PubMed]

108. Semenza, G.L. Hypoxia-inducible factors in physiology and medicine. Cell 2012, 3, 399-408. [CrossRef] [PubMed]

109. Wang, G.L.; Semenza, G.L. Purification and characterization of hypoxia-inducible factor 1. J. Biol. Chem. 1995, 20, 1230-1237. [CrossRef]

110. Wang, G.L.; Jiang, B.H.; Rue, E.A.; Semenza, G.L. Hypoxia-inducible factor 1 is a basic-helix-loop-helix-PAS heterodimer regulated by cellular O2 tension. Proc. Natl. Acad. Sci. USA 1995, 92, 5510-5514. [CrossRef] [PubMed] 
111. Majmundar, A.J.; Wong, W.J.; Simon, M.C. Hypoxia-inducible factors and the response to hypoxic stress. Mol. Cell 2010, 40, 294-309. [CrossRef] [PubMed]

112. Bracken, C.P.; Fedele, A.O.; Linke, S.; Balrak, W.; Lisy, K.; Whitelaw, M.L.; Peet, D.J. Cell-specific regulation of hypoxia-inducible factor (HIF)-1alpha and HIF-2alpha stabilization and transactivation in a graded oxygen environment. J. Biol. Chem. 2006, 281, 22575-22585. [CrossRef] [PubMed]

113. Semenza, G.L. Hydroxylation of HIF-1: Oxygen sensing at the molecular level. Physiology 2004, 19, 176-182. [CrossRef] [PubMed]

114. Hirota, K.; Semenza, G.L. Regulation of hypoxia-inducible factor 1 by prolyl and asparaginyl hydroxylases. Biochem. Biophys. Res. Commun. 2005, 338, 610-616. [CrossRef] [PubMed]

115. Huang, J.; Zhao, Q.; Mooney, S.M.; Lee, F.S. Sequence determinants in hypoxia-inducible factor-1alpha for hydroxylation by the prolyl hydroxylases PHD1, PHD2, and PHD3. J. Biol. Chem. 2002, 277, 39792-39800. [CrossRef] [PubMed]

116. Goldberg, M.A.; Dunning, S.P.; Bunn, H.F. Regulation of the erythropoietin gene: Evidence that the oxygen sensor is a heme protein. Science 1988, 242, 1412-1415. [CrossRef] [PubMed]

117. Semenza, G.L.; Nejfelt, M.K.; Chi, S.M.; Antonarakis, S.E. Hypoxia-inducible nuclear factors bind to an enhancer element located $3^{\prime}$ to the human erythropoietin gene. Proc. Natl. Acad. Sci. USA 1991, 88, 5680-5684. [CrossRef] [PubMed]

118. Snell, C.E.; Turley, H.; McIntyre, A.; Li, D.; Masiero, M.; Schofield, C.J.; Gatter, K.C.; Harris, A.L.; Pezzella, F. Proline-hydroxylated hypoxia-inducible factor $1 \alpha$ (HIF-1 $\alpha)$ upregulation in human tumours. PLoS ONE 2014, 9, e88955. [CrossRef] [PubMed]

119. Zia, M.K.; Rmali, K.A.; Watkins, G.; Mansel, R.E.; Jiang, W.G. The expression of the von Hippel-Lindau gene product and its impact on invasiveness of human breast cancer cells. Int. J. Mol. Med. 2007, 20, 605-611. [CrossRef] [PubMed]

120. Fox, S.B.; Generali, D.; Berruti, A.; Brizzi, M.P.; Campo, L.; Bonardi, S.; Bersiga, A.; Allevi, G.; Milani, M.; Aguggini, S.; et al. The prolyl hydroxylase enzymes are positively associated with hypoxia-inducible factor- $1 \alpha$ and vascular endothelial growth factor in human breast cancer and alter in response to primary systemic treatment with epirubicin and tamoxifen. Breast Cancer Res. 2011, 13, R16. [CrossRef] [PubMed]

121. Baek, S.H.; Kim, K.I. Regulation of HIF-1 $\alpha$ stability by lysine methylation. BMB Rep. 2016, 49, $245-246$. [CrossRef] [PubMed]

122. Soysal, S.D.; Tzankov, A.; Muenst, S.E. Role of the Tumor Microenvironment in Breast Cancer. Pathobiology 2015, 82, 142-152. [CrossRef] [PubMed]

123. Kalluri, R. The biology and function of fibroblasts in cancer. Nat. Rev. Cancer 2016, 23, 582-598. [CrossRef] [PubMed]

124. Polyak, K.; Kalluri, R. The role of the microenvironment in mammary gland development and cancer. Cold Spring Harb. Perspect. Biol. 2010, 2, a003244. [CrossRef] [PubMed]

125. Mao, Y.; Keller, E.T.; Garfield, D.H.; Shen, K.; Wang, J. Stromal cells in tumor microenvironment and breast cancer. Cancer Metastasis Rev. 2013, 32, 303-315. [CrossRef] [PubMed]

126. Polyak, K.; Weinberg, R.A. Transitions between epithelial and mesenchymal states: Acquisition of malignant and stem cell traits. Nat. Rev. Cancer 2009, 9, 265-273. [CrossRef] [PubMed]

127. Zeisberg, E.M.; Potenta, S.; Xie, L.; Zeisberg, M.; Kalluri, R. Discovery of endothelial to mesenchymal transition as a source for carcinoma-associated fibroblasts. Cancer Res. 2007, 67, 10123-10128. [CrossRef] [PubMed]

128. Qiao, A.; Gu, F.; Guo, X.; Zhang, X.; Fu, L. Breast cancer-associated fibroblasts: Their roles in tumor initiation, progression and clinical applications. Front. Med. 2016, 10, 33-40. [CrossRef] [PubMed]

129. Comito, G.; Giannoni, E.; Di Gennaro, P.; Segura, C.P.; Gerlini, G.; Chiarugi, P. Stromal fibroblasts synergize with hypoxic oxidative stress to enhance melanoma aggressiveness. Cancer Lett. 2012, 324, 31-41. [CrossRef] [PubMed]

130. Toullec, A.; Gerald, D.; Despouy, G.; Bourachot, B.; Cardon, M.; Lefort, S.; Richardson, M.; Rigaill, G.; Parrini, M.C.; Lucchesi, C.; et al. Oxidative stress promotes myofibroblast differentiation and tumour spreading. EMBO Mol. Med. 2010, 2, 211-230. [CrossRef] [PubMed]

131. Waghray, M.; Cui, Z.; Horowitz, J.C.; Subramanian, I.M.; Martinez, F.J.; Toews, G.B.; Thannickal, V.J. Hydrogen peroxide is a diffusible paracrine signal for the induction of epithelial cell death by activated myofibroblasts. FASEB J. 2005, 19, 854-856. [CrossRef] [PubMed] 
132. Cirri, P.; Chiarugi, P. Cancer-associated-fibroblasts and tumour cells: A diabolic liaison driving cancer progression. Cancer Metastasis Rev. 2012, 31, 195-208. [CrossRef] [PubMed]

133. Wottawa, M.; Leisering, P.; Ahlen, M.V.; Schnelle, M.; Vogel, S.; Malz, C.; Bordoli, M.R.; Camenisch, G.; Hesse, A.; Napp, J.; et al. Knockdown of prolyl-4-hydroxylase domain 2 inhibits tumor growth of human breast cancer MDA-MB-231 cells by affecting TGF- $\beta 1$ processing. Int. J. Cancer 2013, 132, 2787-2798. [CrossRef] [PubMed]

134. Kuchnio, A.; Dewerchin, M.; Carmeliet, P. The PHD2 oxygen sensor paves the way to metastasis. Oncotarget 2015, 6, 35149-35150. [CrossRef] [PubMed]

135. Madsen, C.D.; Pedersen, J.T.; Venning, F.A.; Singh, L.B.; Moeendarbary, E.; Charras, G.; Cox, T.R.; Sahai, E.; Erler, J.T. Hypoxia and loss of PHD2 inactivate stromal fibroblasts to decrease tumour stiffness and metastasis. EMBO Rep. 2015, 16, 1394-1408. [CrossRef] [PubMed]

136. Chiavarina, B.; Martinez-Outschoorn, U.E.; Whitaker-Menezes, D.; Howell, A.; Tanowitz, H.B.; Pestell, R.G.; Sotgia, F.; Lisanti, M.P. Metabolic reprogramming and two-compartment tumor metabolism: Opposing role(s) of HIF1 $\alpha$ and HIF2 $\alpha$ in tumor-associated fibroblasts and human breast cancer cells. Cell Cycle 2012, 11, 3280-3289. [CrossRef] [PubMed]

137. Migneco, G.; Whitaker-Menezes, D.; Chiavarina, B.; Castello-Cros, R.; Pavlides, S.; Pestell, R.G.; Fatatis, A.; Flomenberg, N.; Tsirigos, A.; Howell, A.; et al. Glycolytic cancer associated fibroblasts promote breast cancer tumor growth, without a measurable increase in angiogenesis: Evidence for stromal-epithelial metabolic coupling. Cell Cycle 2010, 9, 2412-2422. [CrossRef] [PubMed]

138. Costa, A.; Scholer-Dahirel, A.; Mechta-Grigoriou, F. The role of reactive oxygen species and metabolism on cancer cells and their microenvironment. Semin. Cancer Biol. 2014, 25, 23-32. [CrossRef] [PubMed]

139. Martinez-Outschoorn, U.E.; Lisanti, M.P.; Sotgia, F. Catabolic cancer-associated fibroblasts transfer energy and biomass to anabolic cancer cells, fueling tumor growth. Semin. Cancer Biol. 2014, 25, 47-60. [CrossRef] [PubMed]

140. Grivennikov, S.I.; Greten, F.R.; Karin, M. Immunity, inflammation, and cancer. Cell 2010, 140, 883-899. [CrossRef] [PubMed]

141. Haddad, J.J.; Harb, H.L. Cytokines and the regulation of hypoxia-inducible factor (HIF)-1alpha. Int. Immunopharmacol. 2005, 5, 461-483. [CrossRef] [PubMed]

142. Zhou, J.; Brüne, B. Cytokines and hormones in the regulation of hypoxia inducible factor-1alpha (HIF-1alpha). Cardiovasc. Hematol. Agents Med. Chem. 2006, 4, 189-197. [CrossRef] [PubMed]

143. Balamurugan, K. HIF-1 at the crossroads of hypoxia, inflammation, and cancer. Int. J. Cancer 2016, 1, 1058-1066. [CrossRef] [PubMed]

144. Shrivastava, R.; Singh, V.; Asif, M.; Negi, M.P.S.; Bhadauria, S. Oncostatin M upregulates HIF-1 $\alpha$ in breast tumor associated macrophages independent of intracellular oxygen concentration. Life Sci. 2018, 194, 59-66. [CrossRef] [PubMed]

145. Orimo, A.; Gupta, P.B.; Sgroi, D.C.; Arenzana-Seisdedos, F.; Delaunay, T.; Naeem, R.; Carey, V.J.; Richardson, A.L.; Weinberg, R.A. Stromal fibroblasts present in invasive human breast carcinomas promote tumor growth and angiogenesis through elevated SDF-1/CXCL12 secretion. Cell 2005, 6, 335-348. [CrossRef] [PubMed]

146. Andreou, K.; Rajendran, R.; Krstic-Demonacos, M.; Demonacos, C. Regulation of CXCR4 gene expression in breast cancer cells under diverse stress conditions. Int. J. Oncol. 2012, 41, 2253-2259. [CrossRef] [PubMed]

147. Curran, C.S.; Keely, P.J. Breast tumor and stromal cell responses to TGF- $\beta$ and hypoxia in matrix deposition. Matrix Biol. 2013, 32, 95-105. [CrossRef] [PubMed]

148. Dunn, L.K.; Mohammad, K.S.; Fournier, P.G.; McKenna, C.R.; Davis, H.W.; Niewolna, M.; Peng, X.H.; Chirgwin, J.M.; Guise, T.A. Hypoxia and TGF-beta drive breast cancer bone metastases through parallel signaling pathways in tumor cells and the bone microenvironment. PLoS ONE 2009, 4, e6896. [CrossRef] [PubMed]

149. Hung, S.P.; Yang, M.H.; Tseng, K.F.; Lee, O.K. Hypoxia-induced secretion of TGF- $\beta 1$ in mesenchymal stem cell promotes breast cancer cell progression. Cell Transplant. 2013, 22, 1869-1882. [CrossRef] [PubMed]

150. Stantic, M.; Sakil, H.A.; Zirath, H.; Fang, T.; Sanz, G.; Fernandez-Woodbridge, A.; Marin, A.; Susanto, E.; Mak, T.W.; Henriksson, M.A.; et al. TAp73 suppresses tumor angiogenesis through repression of proangiogenic cytokines and HIF-1 $\alpha$ activity. Proc. Natl. Acad. Sci. USA 2015, 112, 220-225. [CrossRef] [PubMed] 
151. Sanguinetti, A.; Santini, D.; Bonafè, M.; Taffurelli, M.; Avenia, N. Interleukin-6 and pro inflammatory status in the breast tumor microenvironment. World J. Surg. Oncol. 2015, 13, 129. [CrossRef] [PubMed]

152. Studebaker, A.W.; Storci, G.; Werbeck, J.L.; Sansone, P.; Sasser, A.K.; Tavolari, S.; Huang, T.; Chan, M.W.; Marini, F.C.; Rosol, T.J.; et al. Fibroblasts isolated from common sites of breast cancer metastasis enhance cancer cell growth rates and invasiveness in an interleukin-6-dependent manner. Cancer Res. 2008, 68, 9087-9095. [CrossRef] [PubMed]

153. Wang, D.; Xu, J.; Liu, B.; He, X.; Zhou, L.; Hu, X.; Qiao, F.; Zhang, A.; Xu, X.; Zhang, H.; et al. IL6 blockade potentiates the anti-tumor effects of $\gamma$-secretase inhibitors in Notch3-expressing breast cancer. Cell Death Differ. 2018, 25, 330-339. [CrossRef] [PubMed]

154. Kong, W.; He, L.; Richards, E.J.; Challa, S.; Xu, C.X.; Permuth-Wey, J.; Lancaster, J.M.; Coppola, D.; Sellers, T.A.; Djeu, J.Y.; et al. Upregulation of miRNA-155 promotes tumour angiogenesis by targeting VHL and is associated with poor prognosis and triple-negative breast cancer. Oncogene 2014, 33, 679-689. [CrossRef] [PubMed]

155. Ren, Y.; Zhou, X.; Liu, X.; Jia, H.H.; Zhao, X.H.; Wang, Q.X.; Han, L.; Song, X.; Zhu, Z.Y.; Sun, T.; et al. Reprogramming carcinoma associated fibroblasts by AC1MMYR2 impedes tumor metastasis and improves chemotherapy efficacy. Cancer Lett. 2016, 374, 96-106. [CrossRef] [PubMed]

156. Liu, Y.V.; Baek, J.H.; Zhang, H.; Diez, R.; Cole, R.N.; Semenza, G.L. RACK1 competes with HSP90 for binding to HIF-1alpha and is required for O(2)-independent and HSP90 inhibitor-induced degradation of HIF-1alpha. Mol. Cell 2007, 25, 207-217. [CrossRef] [PubMed]

157. Dewhirst, M.W.; Cao, Y.; Moeller, B. Cycling hypoxia and free radicals regulate angiogenesis and radiotherapy response. Nat. Rev. Cancer 2008, 8, 425-437. [CrossRef] [PubMed]

158. Iommarini, L.; Porcelli, A.M.; Gasparre, G.; Kurelac, I. Non-Canonical Mechanisms Regulating Hypoxia-Inducible Factor 1 Alpha in Cancer. Front. Oncol. 2017, 7, 286. [CrossRef] [PubMed]

159. Kazi, A.A.; Gilani, R.A.; Schech, A.J.; Chumsri, S.; Sabnis, G.; Shah, P.; Goloubeva, O.; Kronsberg, S.; Brodie, A.H. Nonhypoxic regulation and role of hypoxia-inducible factor 1 in aromatase inhibitor resistant breast cancer. Breast Cancer Res. 2014, 16, R15. [CrossRef] [PubMed]

160. Carroll, V.A.; Ashcroft, M. Role of hypoxia-inducible factor (HIF)-1alpha versus HIF-2alpha in the regulation of HIF target genes in response to hypoxia, insulin-like growth factor-I, or loss of von Hippel-Lindau function: Implications for targeting the HIF pathway. Cancer Res. 2006, 66, 6264-6270. [CrossRef] [PubMed]

161. Tang, X.D.; Zhou, X.; Zhou, K.Y. Dauricine inhibits insulin-like growth factor-I-induced hypoxia inducible factor 1alpha protein accumulation and vascular endothelial growth factor expression in human breast cancer cells. Acta Pharmacol. Sin. 2009, 30, 605-616. [CrossRef] [PubMed]

162. De Francesco, E.M.; Sims, A.H.; Maggiolini, M.; Sotgia, F.; Lisanti, M.P.; Clarke, R.B. GPER mediates the angiocrine actions induced by IGF1 through the HIF-1 $\alpha$ /VEGF pathway in the breast tumor microenvironment. Breast Cancer Res. 2017, 19, 129. [CrossRef] [PubMed]

163. Samanta, D.; Gilkes, D.M.; Chaturvedi, P.; Xiang, L.; Semenza, G.L. Hypoxia-inducible factors are required for chemotherapy resistance of breast cancer stem cells. Proc. Natl. Acad. Sci. USA 2014, 111, E5429-5438. [CrossRef] [PubMed]

164. Rigiracciolo, D.C.; Scarpelli, A.; Lappano, R.; Pisano, A.; Santolla, M.F.; De Marco, P.; Cirillo, F.; Cappello, A.R.; Dolce, V.; Belfiore, A.; et al. Copper activates HIF-1 $\alpha /$ GPER/VEGF signalling in cancer cells. Oncotarget 2015, 6, 34158-34177. [CrossRef] [PubMed]

165. De Francesco, E.M.; Pellegrino, M.; Santolla, M.F.; Lappano, R.; Ricchio, E.; Abonante, S.; Maggiolini, M. GPER mediates activation of HIF1 $\alpha$ /VEGF signaling by estrogens. Cancer Res. 2014, 74, 4053-4064. [CrossRef] [PubMed]

166. Bartella, V.; De Francesco, E.M.; Perri, M.G.; Curcio, R.; Dolce, V.; Maggiolini, M.; Vivacqua, A. The G protein estrogen receptor (GPER) is regulated by endothelin-1 mediated signaling in cancer cells. Cell. Signal. 2016, 28, 61-71. [CrossRef] [PubMed]

167. Karin, M.; Liu, Z.; Zandi, E. AP-1 function and regulation. Curr. Opin. Cell Biol. 1997, 9, 240-246. [CrossRef]

168. Kazi, A.A.; Jones, J.M.; Koos, R.D. Chromatin immunoprecipitation analysis of gene expression in the rat uterus in vivo: Estrogen-induced recruitment of both estrogen receptor alpha and hypoxia-inducible factor 1 to the vascular endothelial growth factor promoter. Mol. Endocrinol. 2005, 19, 2006-2019. [CrossRef] [PubMed] 
169. Hua, K.; Din, J.; Cao, Q.; Feng, W.; Zhang, Y.; Yao, L.; Huang, Y.; Zhao, Y.; Feng, Y. Estrogen and progestin regulate HIF-1alpha expression in ovarian cancer cell lines via the activation of Akt signaling transduction pathway. Oncol. Rep. 2009, 21, 893-898. [PubMed]

170. George, A.L.; Rajoria, S.; Suriano, R.; Mittleman, A.; Tiwari, R.K. Hypoxia and estrogen are functionally equivalent in breast cancer-endothelial cell interdependence. Mol. Cancer 2012, 11, 80. [CrossRef] [PubMed]

171. Kazi, A.A.; Koos, R.D. Estrogen-induced activation of hypoxia-inducible factor-1alpha, vascular endothelial growth factor expression, and edema in the uterus are mediated by the phosphatidylinositol 3-kinase/Akt pathway. Endocrinology 2007, 148, 2363-2374. [CrossRef] [PubMed]

172. Padró, M.; Louie, R.J.; Lananna, B.V.; Krieg, A.J.; Timmerman, L.A.; Chan, D.A. Genome-independent hypoxic repression of estrogen receptor alpha in breast cancer cells. BMC Cancer 2017, 17, 203. [CrossRef] [PubMed]

173. Frump, A.L.; Selej, M.; Wood, J.A.; Albrecht, M.; Yakubov, B.; Petrache, I.; Lahm, T. Hypoxia Up-regulates Estrogen Receptor $\beta$ in Pulmonary Artery Endothelial Cells in a HIF-1 $\alpha$ Dependent Manner. Am. J. Respir. Cell. Mol. Biol. 2018. [CrossRef] [PubMed]

174. Recchia, A.G.; De Francesco, E.M.; Vivacqua, A.; Sisci, D.; Panno, M.L.; Andò, S.; Maggiolini, M. The G protein-coupled receptor 30 is up-regulated by hypoxia-inducible factor-1alpha (HIF-1alpha) in breast cancer cells and cardiomyocytes. J. Biol. Chem. 2011, 286, 10773-10782. [CrossRef] [PubMed]

175. Bos, R.; Zhong, H.; Hanrahan, C.F.; Mommers, E.C.; Semenza, G.L.; Pinedo, H.M.; Abeloff, M.D.; Simons, J.W.; van Diest, P.J.; van der Wall, E. Levels of hypoxia-inducible factor-1 alpha during breast carcinogenesis. J. Natl. Cancer Inst. 2001, 93, 309-314. [CrossRef] [PubMed]

176. Brunnberg, S.; Pettersson, K.; Rydin, E.; Matthews, J.; Hanberg, A.; Pongratz, I. The basic helix-loop-helix-PAS protein ARNT functions as a potent coactivator of estrogen receptor-dependent transcription. Proc. Natl. Acad. Sci. USA 2003, 100, 6517-6522. [CrossRef] [PubMed]

177. Ryu, K.; Park, C.; Lee, Y. Hypoxia-inducible factor 1 alpha represses the transcription of the estrogen receptor alpha gene in human breast cancer cells. Biochem. Biophys. Res. Commun. 2011, 407, 831-836. [CrossRef] [PubMed]

178. Cho, J.; Kim, D.; Lee, S.; Lee, Y. Cobalt chloride-induced estrogen receptor alpha down-regulation involves hypoxia-inducible factor-1alpha in MCF-7 human breast cancer cells. Mol. Endocrinol. 2005, 19, 1191-1199. [CrossRef] [PubMed]

179. Kronblad, A.; Helczynska, K.; Nielsen, N.H.; Påhlman, E.; Emdin, S.; Påhlman, S.; Landberg, G. Regional cyclin D1 overexpression or hypoxia correlate inversely with heterogeneous oestrogen receptor-alpha expression in human breast cancer. In Vivo 2003, 17, 311-318. [PubMed]

180. Kronblad, A.; Hedenfalk, I.; Nilsson, E.; Påhlman, S.; Landberg, G. ERK1/2 inhibition increases antiestrogen treatment efficacy by interfering with hypoxia-induced downregulation of ERalpha: A combination therapy potentially targeting hypoxic and dormant tumor cells. Oncogene. 2005, 24, 6835-6841. [CrossRef] [PubMed]

181. Ogba, N.; Doughman, Y.Q.; Chaplin, L.J.; Hu, Y.; Gargesha, M.; Watanabe, M.; Montano, M.M. HEXIM1 modulates vascular endothelial growth factor expression and function in breast epithelial cells and mammary gland. Oncogene 2010, 29, 3639-3649. [CrossRef] [PubMed]

182. Sudhagar, S.; Sathya, S.; Lakshmi, B.S. Rapid non-genomic signalling by $17 \beta$-oestradiol through c-Src involves mTOR-dependent expression of HIF-1 $\alpha$ in breast cancer cells. Br. J. Cancer 2011, 105, 953-960. [CrossRef] [PubMed]

183. Harrison, H.; Rogerson, L.; Gregson, H.J.; Brennan, K.R.; Clarke, R.B.; Landberg, G. Contrasting hypoxic effects on breast cancer stem cell hierarchy is dependent on ER- $\alpha$ status. Cancer Res. 2013, 73, 1420-1433. [CrossRef] [PubMed]

184. Yang, J.; AlTahan, A.; Jones, D.T.; Buffa, F.M.; Bridges, E.; Interiano, R.B.; Qu, C.; Vogt, N.; Li, J.L.; Baban, D.; et al. Estrogen receptor- $\alpha$ directly regulates the hypoxia-inducible factor 1 pathway associated with antiestrogen response in breast cancer. Proc. Natl. Acad. Sci. USA 2015, 112, 15172-15177. [CrossRef] [PubMed]

185. Yang, J.; Jubb, A.M.; Pike, L.; Buffa, F.M.; Turley, H.; Baban, D.; Leek, R.; Gatter, K.C.; Ragoussis, J.; Harris, A.L. The histone demethylase JMJD2B is regulated by estrogen receptor alpha and hypoxia, and is a key mediator of estrogen induced growth. Cancer Res. 2010, 70, 6456-6466. [CrossRef] [PubMed] 
186. Fuady, J.H.; Gutsche, K.; Santambrogio, S.; Varga, Z.; Hoogewijs, D.; Wenger, R.H. Estrogen-dependent downregulation of hypoxia-inducible factor (HIF)-2 $\alpha$ in invasive breast cancer cells. Oncotarget 2016, 7, 31153-31165. [CrossRef] [PubMed]

187. Lim, W.; Park, Y.; Cho, J.; Park, C.; Park, J.; Park, Y.K.; Park, H.; Lee, Y. Estrogen receptor beta inhibits transcriptional activity of hypoxia inducible factor-1 through the downregulation of arylhydrocarbon receptor nuclear translocator. Breast Cancer Res. 2011, 13, R32. [CrossRef] [PubMed]

188. Park, C.; Lee, Y. Overexpression of ER $\beta$ is sufficient to inhibit hypoxia-inducible factor-1 transactivation. Biochem. Biophys. Res. Commun. 2014, 450, 261-266. [CrossRef] [PubMed]

189. Koda, M.; Kanczuga-Koda, L.; Sulkowska, M.; Surmacz, E.; Sulkowski, S. Relationships between hypoxia markers and the leptin system, estrogen receptors in human primary and metastatic breast cancer: Effects of preoperative chemotherapy. BMC Cancer 2010, 10, 320. [CrossRef] [PubMed]

190. Bialesova, L.; Xu, L.; Gustafsson, J.Å.; Haldosen, L.A.; Zhao, C.; Dahlman-Wright, K. Estrogen receptor $\beta 2$ induces proliferation and invasiveness of triple negative breast cancer cells: Association with regulation of PHD3 and HIF-1 $\alpha$. Oncotarget 2017, 8, 76622-76633. [CrossRef] [PubMed]

191. De Francesco, E.M.; Lappano, R.; Santolla, M.F.; Marsico, S.; Caruso, A.; Maggiolini, M. HIF- $1 \alpha /$ GPER signaling mediates the expression of VEGF induced by hypoxia in breast cancer associated fibroblasts (CAFs). Breast Cancer Res. 2013, 15, R64. [CrossRef] [PubMed]

192. Ren, J.; Guo, H.; Wu, H.; Tian, T.; Dong, D.; Zhang, Y.; Sui, Y.; Zhang, Y.; Zhao, D.; Wang, S.; et al. GPER in CAFs regulates hypoxia-driven breast cancer invasion in a CTGF-dependent manner. Oncol. Rep. 2015, 33, 1929-1937. [CrossRef] [PubMed]

193. Yu, T.; Yang, G.; Hou, Y.; Tang, X.; Wu, C.; Wu, X.A.; Guo, L.; Zhu, Q.; Luo, H.; Du, Y.E. Cytoplasmic GPER translocation in cancer-associated fibroblasts mediates cAMP/PKA/CREB/glycolytic axis to confer tumor cells with multidrug resistance. Oncogene 2017, 36, 2131-2145. [CrossRef] [PubMed]

194. Sonveaux, P.; Copetti, T.; De Saedeleer, C.J.; Végran, F.; Verrax, J.; Kennedy, K.M.; Moon, E.J.; Dhup, S.; Danhier, P.; Frérart, F.; et al. Targeting the lactate transporter MCT1 in endothelial cells inhibits lactate-induced HIF-1 activation and tumor angiogenesis. PLoS ONE 2012, 7, e33418. [CrossRef] [PubMed]

195. Lu, H.; Forbes, R.A.; Verma, A. Hypoxia-inducible factor 1 activation by aerobic glycolysis implicates the Warburg effect in carcinogenesis. J. Biol. Chem. 2002, 277, 23111-23115. [CrossRef] [PubMed]

196. Jung, S.Y.; Song, H.S.; Park, S.Y.; Chung, S.H.; Kim, Y.J. Pyruvate promotes tumor angiogenesis through HIF-1-dependent PAI-1 expression. Int. J. Oncol. 2011, 38, 571-576. [PubMed]

197. Zhang, L.; Xiong, W.; Li, N.; Liu, H.; He, H.; Du, Y.; Zhang, Z.; Liu, Y. Estrogen stabilizes hypoxia-inducible factor $1 \alpha$ through $G$ protein-coupled estrogen receptor 1 in eutopic endometrium of endometriosis. Fertil. Steril. 2017, 107, 439-447. [CrossRef] [PubMed]

198. Xu, F.; Wang, X.; Wu, N.; He, S.; Yi, W.; Xiang, S.; Zhang, P.; Xie, X.; Ying, C. Bisphenol A induces proliferative effects on both breast cancer cells and vascular endothelial cells through a shared GPER-dependent pathway in hypoxia. Environ. Pollut. 2017, 231, 1609-1620. [CrossRef] [PubMed]

199. Weißenborn, C.; Ignatov, T.; Ochel, H.J.; Costa, S.D.; Zenclussen, A.C.; Ignatova, Z.; Ignatov, A. GPER functions as a tumor suppressor in triple-negative breast cancer cells. J. Cancer Res. Clin. Oncol. 2014, 140, 713-723. [CrossRef] [PubMed]

200. Chen, Z.J.; Wei, W.; Jiang, G.M.; Liu, H.; Wei, W.D.; Yang, X.; Wu, Y.M.; Liu, H.; Wong, C.K.; Du, J.; et al. Activation of GPER suppresses epithelial mesenchymal transition of triple negative breast cancer cells via NF-kB signals. Mol. Oncol. 2016, 10, 775-788. [CrossRef] [PubMed]

201. Liang, S.; Chen, Z.; Jiang, G.; Zhou, Y.; Liu, Q.; Su, Q.; Wei, W.; Du, J.; Wang, H. Activation of GPER suppresses migration and angiogenesis of triple negative breast cancer via inhibition of NF- $\mathrm{KB} / \mathrm{IL}-6$ signals. Cancer Lett. 2017, 386, 12-23. [CrossRef] [PubMed]

202. Jia, X.; Hong, Q.; Lei, L.; Li, D.; Li, J.; Mo, M.; Wang, Y.; Shao, Z.; Shen, Z.; Cheng, J.; et al. Basal and therapy-driven hypoxia-inducible factor- $1 \alpha$ confers resistance to endocrine therapy in estrogen receptor-positive breast cancer. Oncotarget 2015, 6, 8648-8662. [CrossRef] [PubMed]

203. Theys, J.; Jutten, B.; Habets, R.; Paesmans, K.; Groot, A.J.; Lambin, P.; Wouters, B.G.; Lammering, G.; Vooijs, M. E-Cadherin loss associated with EMT promotes radioresistance in human tumor cells. Radiother. Oncol. 2011, 99, 392-397. [CrossRef] [PubMed] 
204. Borggrefe, T.; Lauth, M.; Zwijsen, A.; Huylebroeck, D.; Oswald, F.; Giaimo, B.D. The Notch intracellular domain integrates signals from Wnt, Hedgehog, TGF $\beta /$ BMP and hypoxia pathways. Biochim. Biophys. Acta 2016, 1863, 303-313. [CrossRef] [PubMed]

205. Pupo, M.; Vivacqua, A.; Perrotta, I.; Pisano, A.; Aquila, S.; Abonante, S.; Gasperi-Campani, A.; Pezzi, V.; Maggiolini, M. The nuclear localization signal is required for nuclear GPER translocation and function in breast Cancer-Associated Fibroblasts (CAFs). Mol. Cell. Endocrinol. 2013, 376, 23-32. [CrossRef] [PubMed]

206. Yuan, X.; Wu, H.; Xu, H.; Xiong, H.; Chu, Q.; Yu, S.; Wu, G.S.; Wu, K. Notch signaling: An emerging therapeutic target for cancer treatment. Cancer Lett. 2015, 369, 20-27. [CrossRef] [PubMed]

207. Li, K.; Li, Y.; Wu, W.; Gordon, W.R.; Chang, D.W.; Lu, M.; Scoggin, S.; Fu, T.; Vien, L.; Histen, G.; et al. Modulation of Notch signaling by antibodies specific for the extracellular negative regulatory region of NOTCH3. J. Biol. Chem. 2008, 283, 8046-8054. [CrossRef] [PubMed]

208. Wu, Y.; Cain-Hom, C.; Choy, L.; Hagenbeek, T.J.; de Leon, G.P.; Chen, Y.; Finkle, D.; Venook, R.; Wu, X.; Ridgway, J.; et al. Therapeutic antibody targeting of individual Notch receptors. Nature 2010, 464, 1052-1057. [CrossRef] [PubMed]

209. Jenkins, D.W.; Ross, S.; Veldman-Jones, M.; Foltz, I.N.; Clavette, B.C.; Manchulenko, K.; Eberlein, C.; Kendrew, J.; Petteruti, P.; Cho, S.; et al. MEDI0639: A novel therapeutic antibody targeting Dll4 modulates endothelial cell function and angiogenesis in vivo. Mol. Cancer Ther. 2012, 11, 1650-1660. [CrossRef] [PubMed]

210. Funahashi, Y.; Hernandez, S.L.; Das, I.; Ahn, A.; Huang, J.; Vorontchikhina, M.; Sharma, A.; Kanamaru, E.; Borisenko, V.; Desilva, D.M.; et al. A notch1 ectodomain construct inhibits endothelial notch signaling, tumor growth, and angiogenesis. Cancer Res. 2008, 68, 4727-4735. [CrossRef] [PubMed]

211. Kangsamaksin, T.; Murtomaki, A.; Kofler, N.M.; Cuervo, H.; Chaudhri, R.A.; Tattersall, I.W.; Rosenstiel, P.E.; Shawber, C.J.; Kitajewski, J. NOTCH decoys that selectively block DLL/NOTCH or JAG/NOTCH disrupt angiogenesis by unique mechanisms to inhibit tumor growth. Cancer Discov. 2015, 5, 182-197. [CrossRef] [PubMed]

212. Moellering, R.E.; Cornejo, M.; Davis, T.N.; Del Bianco, C.; Aster, J.C.; Blacklow, S.C.; Kung, A.L.; Gilliland, D.G.; Verdine, G.L.; Bradner, J.E. Direct inhibition of the NOTCH transcription factor complex. Nature 2009, 462, 182-188. [CrossRef] [PubMed]

213. Astudillo, L.; Da Silva, T.G.; Wang, Z.; Han, X.; Jin, K.; VanWye, J.; Zhu, X.; Weaver, K.; Oashi, T.; Lopes, P.E.; et al. The Small Molecule IMR-1 Inhibits the Notch Transcriptional Activation Complex to Suppress Tumorigenesis. Cancer Res. 2016, 76, 3593-3603. [CrossRef] [PubMed]

214. Krämer, A.; Mentrup, T.; Kleizen, B.; Rivera-Milla, E.; Reichenbach, D.; Enzensperger, C.; Nohl, R.; Täuscher, E.; Görls, H.; Ploubidou, A.; et al. Small molecules intercept Notch signaling and the early secretory pathway. Nat. Chem. Biol. 2013, 9, 731-738. [CrossRef] [PubMed]

215. Roti, G.; Carlton, A.; Ross, K.N.; Markstein, M.; Pajcini, K.; Su, A.H.; Perrimon, N.; Pear, W.S.; Kung, A.L.; Blacklow, S.C.; et al. Complementary genomic screens identify SERCA as a therapeutic target in NOTCH1 mutated cancer. Cancer Cell 2013, 23, 390-405. [CrossRef] [PubMed]

216. Pandya, K.; Meeke, K.; Clementz, A.G.; Rogowski, A.; Roberts, J.; Miele, L.; Albain, K.S.; Osipo, C. Targeting both Notch and ErbB-2 signalling pathways is required for prevention of ErbB-2-positive breast tumour recurrence. Br. J. Cancer 2011, 105, 796-806. [CrossRef] [PubMed]

217. Schott, A.F.; Landis, M.D.; Dontu, G.; Griffith, K.A.; Layman, R.M.; Krop, I.; Paskett, L.A.; Wong, H.; Dobrolecki, L.E.; Lewis, M.T.; et al. Preclinical and clinical studies of gamma secretase inhibitors with docetaxel on human breast tumors. Clin. Cancer Res. 2013, 19, 1512-1524. [CrossRef] [PubMed]

218. Zhang, C.C.; Yan, Z.; Zong, Q.; Fang, D.D.; Painter, C.; Zhang, Q.; Chen, E.; Lira, M.E.; John-Baptiste, A.; Christensen, J.G. Synergistic effect of the $\gamma$-secretase inhibitor PF-03084014 and docetaxel in breast cancer models. Stem Cells Transl. Med. 2013, 2, 233-242. [CrossRef] [PubMed]

(C) 2018 by the authors. Licensee MDPI, Basel, Switzerland. This article is an open access article distributed under the terms and conditions of the Creative Commons Attribution (CC BY) license (http:/ / creativecommons.org/licenses/by/4.0/). 